Trakya Eğitim Dergisi

Cilt 9, Sayı 4

2019 Ek Sayı

Aralık 2019, 824-846

Geliş Tarihi: 26.02 .2019

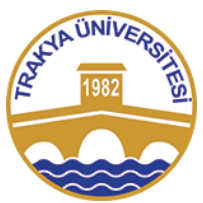

ISSN: 2630-6301
Trakya Journal of Education

Volume 9, Issue 4

2019 Additional Issue

December 2019, 824-846

Yayına Kabul Tarihi: 06.12.2019

DOI:10.24315/tred.532641

Araştırma Makalesi

\title{
Öğretmenlerin “Öğretmenlik Mesleğinin İmajı” Hakkındaki Görüşleri ${ }^{1}$
}

\author{
The Opinions Of The Teachers On "The Image Of The Teaching Profession
}

\section{Tuncay Yavuz ÖZDEMIR ${ }^{2}$, Mustafa ORHAN ${ }^{3}$}

\begin{abstract}
Öz: $\mathrm{Bu}$ araştırmanın amacı, Elazığ ilindeki ilkokul, ortaokul ve liselerde görev yapan öğretmenlerin "öğretmenlik mesleğinin imajı" hakkındaki görüşlerini belirlemektir. $\mathrm{Bu}$ araştırma, nitel araştırma yöntemleri arasında yer alan olgu bilim (fenomenoloji) deseninde gerçekleştirilmiştir. Araştırmanın çalışma grubunu 2017-2018 eğitim öğretim yılında Elazığ ilindeki ilkokul, ortaokul ve liselerde görev yapan öğretmenler oluşturmaktadır. Katılımcılar ile ön görüşmeler yapılarak, görüşlerini belirtmekten kaçınmayacaklarını belirten 40 öğretmen çalışma grubuna dahil edilmiştir. Araştırma verileri, yarı yapılandırılmış görüşme formu ile elde edilmiştir. Elde edilen verilerin analizinde içerik analizi yöntemi kullanılmıştır. Araştırma sonuçlarına göre, öğretmenler öğretmenlik mesleği imajını genel olarak olumsuz gördüklerini ve mesleki imajlarının geçmişe oranla daha kötü durumda olduğunu belirtmişlerdir. Mesleki imajlarına katkıda bulunmak için öğretmenlerin yapması gerekenlerde, en fafzla kendini geliştirme-yenileme ifadesi; Milli Eğitim Bakanlığı ve siyasilerin yapması gerekenlerde ise, ekonomik şartlar iyileştirilmeli ve öğretmenlere saygı gösterilmeli-değer verilmeli ifadeleri ön plana çıkmıştır.
\end{abstract}

Anahtar sözcükler: İlkokul, ortaokul, lise, imaj, öğretmenlik, meslek.

\begin{abstract}
The aim of this research is to determine the opinions of the teachers, working for primary, secondary and high schools of Elazığ Provincial, about "the image of the teaching profession." This research was realised in a phenomenological pattern which is located in the qualitative research methods. The study group of the research is composed of primary, secondary and high school teachers working for Elazı $\breve{g}$ Provincial in the school year of 20172018. By carrying out the preliminary interviews with the participants, forty teachers were included in the study group who indicated that they would not avoid expressing their opinions. The data of the research was obtained from semi-structured interview form. The content analysis method was used in the analysis of the data obtained. According to the results of the research, the teachers stated that they regarded the image of the teaching profession as negative in general and their professional image is worse as compared with the past. The statement of improving and renovating himself/herself at most in the requirements of teachers to contribute their professional image, As for the requirements of Ministry of National Education and politicians, The statements that economic situations should enchanced and teachers should be respected and given value come into prominence.
\end{abstract}

Keywords: Primary school, secondary school, high school, image, teaching, profession.

\section{EXTENDED ABSTRACT}

\section{Introduction}

Teacher is a professional person who provide terminal behaviour in education environment (Sönmez, 2004). The teacher who is the most important part of system of education, is responsible for the new generations to become beneficial for the society and is responsible for raising the man power that society need. The duty of the school and the teacher is to train child and turn the non-educational experiences, they got as a result of occasionally his/her interaction of environment, into the educational way (Küçükahmet, 2003). When it comes to profession of teaching, description and concept of this profession, not only the duty and responsibilities of the people carrying out this profession as well as the expectations of the society from teachers, but also the image of this profession which is shaped in the minds comes into minds.

The image is described as a process of making judgement of a person about the other person (people, companies, occupations, non-govermental organisations, groups, states etc.) (Ünsal, 2015). On the other hand, the occupational image is the total of perceptions of the main related people such as customers, bosses, superiors, inferiors and colleagues related to the suffeciency and character of a worker (Roberts,

\footnotetext{
${ }^{1} \mathrm{Bu}$ çalışmanın bir bölümü 10-12 Mayıs 2018 tarihlerinde Sivas Cumhuriyet Üniversitesi'nde gerçekleştirilen 13. Uluslararas1 Eğitim Yönetimi Kongresi’nde sözlü bildiri olarak sunulmuştur.

2 Doç. Dr., Fırat Üniversitesi, Eğitim Fakültesi, Eğitim Bilimleri Bölümü, Elazı̆̆-Tüekiye, tyozdemir@ firat.edu.tr, ORCID ID:0000-0002-5361-7261

3. Doktora Öğrencisi, Fırat Üniversitesi, Eğitim Bilimleri Enstitüsü, Elazı ̆̆-Türkiye, mustafaorhan2525@hotmail.com, ORCID ID:0000-0002-6254-6733
} 
2005). While people make an evaulation about the image of an occupation, they take into consideration of the appearances, behaviours, speeches, body languages, the people carrying out that profession, clothes, the messages they sent by means of achievements. These messages consist of the image of profession (Bağçeci, Çetin and Ünsal, 2013).

The question of how the profession of teaching which plays quite important role in society and takes the important responsibility such as training qualified man power for the development of the country correspondingly is perceived, forms the basic motivation of the research. The issue of how this profession is perceived especially by the people carrying out this profession of teaching is seen as important by the researchers with regard to provide introspection into the the profession of teaching. The aim of this research is to determine the opinions of the teachers working in primary, secondary and high schools depending on Elazığ Province about the 'image of teaching profession'. The answers were searched to the following questions within the scope of general goals.

What do the teachers think about the images of their profession?

How do the teachers make evaulations when they compare their present images of profession with the past images of profession?

What can be done to improve image of teaching profession?

\section{Method}

This research was realised on the pattern of phenomenology which is placed among the qualitative researches. The study group of the research was formed by the teachers working in primary, secondary and high schools depending on Elazı ğ Province in 2017/2018 academic year. By making pre-interwiews with the participants, 40 teachers, who stated that they wouldn't avoid expressing their opinions, were included into the study group. The search data were obtained from the semi-structured interview form which was developed by the researchers and consisted of open ended questions. Content analysis method was used for analysis of the data obtained from the participants in the research.

\section{Result And Discussion}

In the result of research that aims at determinig the the opinions of the teachers working in primary, secondary and high schools depending on Elazı $\breve{g}$ Province about the 'image of teaching profession', The following results were reached.

7 out of 40 teachers who participated in the research stated that they had positive opinions about their image of profession, 33 out of 40 teachers who participated in the research stated that they had negative opinions about their image of profession. The teachers, who stated positive opinions about their image of profession, explained this considering the fact that the teaching generally must be seen as respectful occupation in every period, the role of teachers in training future generations is important and they are models for the society. The teachers, who stated negative opinions about their image of profession, expressed that the image of profession was affected negatively by the behaviours of teachers, the viewpoint of society, the approach of politicians. The factors of incompetency of teacher training, the lack of the points in the teacher's communication, clothing, and behaviours, negative approaches of parents and the students to the teachers, available complain lines, not giving value to the teachers, not consulting them, teacher's having no effects on students, the thoughts of gaining low salary, the perception that teaching is a easy and rememebered with holidays come into prominence in teachers' perception of their image of profession negatively. The perception of teachers' that their social status and their social and economic conditions are not sufficient may cause teachers to have highly negative thoughts about their image of profession. The findings of this study have similarity with the findings of the study of TEDMEM (2014), Sözer (2015), Ünsal and Bağçeci (2016), Ulutaş (2017) and TALIS 2013 [Teaching and Learning International Survey] made by OECD (2014). On the contrary, the findings of this study have difference from the findings of the study of Ceviz (2018), Yurdakul, Gür, Çelik and Kurt (2016) and Everton, Turner, Hargreaves and Pell (2007). 3 out of 40 teachers participated in research stated that their image of profession was the same with the past relatively, 37 out of 40 teachers participated in research stated that their image of profession was worse than the past relatively. The teachers who stated that their image of profession was worse than the past relatively, explained this with folllowing statements: The view point of the society, wrongness in the choosing and appointing the teachers, vocational incompetency, the difficulties in appointing the candidate teachers in proportion to the past, the perception of teaching as an easy occupation, consideration of teaching as only craft or a occupation, the reduction in importance of teacher together with the easy access to information, giving less respect to the teachers than the past reletively and giving less value, not paying attention to the thoughts of teachers, the opinions that teachers make less sacrifice than the past relatively. Perceptions of teachers that economic and social changes negatively affect the meaning 
attributed to the profession of teaching may cause them to state highly the opininon that image of teachers' profession is worse than the past relatively. The findings of this study have similarity with the findings of the study of TEDMEM (2014), Ünsal and Bağçeci (2016), Yurdakul, Gür, Çelik and Kurt (2016) and Hargreaves and the others (2007).

The statement of improving and renovating themselves at most came into prominence in teachers' necessity for contributing the image of profession. Model behaviours presentation, speaking, taking care of behaviour and clothing, having vocational consciousness and responsibility, being self sacrificied and solution oriented were expresssed as other necessities for the teachers to contribute to the image of their profession. The fact that teachers state the point of improving and renovating themselves in order to contribute to the teachers' image of profession emphasizes on point of the competency of fullfilling their social demands. It may be the perception that the fullfilling the social demands will be able to have contributions to the image of their professions in expressing that opinions highly. It can be said that The findings of this study have similarity with the findings of the study of Ünsal and Bağçeci (2016).

The statements that economic conditions must be enhanced most and teachers must be respected and given value, appeared in the necessity of MEB (Ministry Of National Education) and politicians to contribute the image of profession. The other necessities of MEB (Ministry Of National Education) and politicians to contribute the image of profession were stated as followings: education and teacher must not be abused to the politics, empleyees' personal and legal rights must be enhanced and the conditions of the school must be enhanced. The perceptions that good economic conditions provide good image may cause them to state highly the opinions of enhancing the economic conditions in order to contribute to the teachers' image of profession. Similarly, the fact that the opinions of respecting and giving value to the teachers were stated by the teachers highly in order to contribute to the teachers' image of profession may arise from the perception that their image of professions which is respected and given value will be better. It can be said that The findings of this study have similarity with the findings of the study of Hargreaves and the others (2006), Ünsal and Bağçeci (2016) and Ünsal (2018).

\section{GİRIŞ}

Bir kişi, kurum, marka, ülke ya da insan topluluğu hakkında değerlendirmede bulunurken, bunların hem birey hem de toplum zihninde oluşturduğu resimden hareket edilmektedir. Değerlendirme yapılan kavram veya olgunun etki büyüklüğü kişisel ve toplumsal bakış1 etkiler. Diğer mesleklerde olduğu gibi öğretmenlik mesleğinin de insanların zihin dünyalarında şekillenen bir resmi mevcuttur. Eskiden beri Türk toplumunda, öğretmenlere yakın ilgi gösterilmiş, sayg1 ve sevgi duyulmuştur (Kılıç, 2018). Meslek, "belli bir eğitim ile kazanılan sistemli bilgi ve becerilere dayalı, insanlara yararlı mal üretmek, hizmet vermek ve karşılığında para kazanmak için yapılan, kuralları belirlenmiş iş" (TDK, www.tdk.gov.tr.) olarak tanımlanmaktadır. Bunun yanı sıra meslek, bir kişinin, hayattaki ihtiyaçlarını karşılayacak şekilde para kazanmak için yaptığı sürekli iş/uğraş olarak ifade edilirken, öğretmenlik mesleği de öğretmenin, hayattaki ihtiyaçlarını karşılayacak şekilde para kazanması için yaptığı sürekli öğretme işi/görevi olarak tanımlanabilir (Akbaşl1, 2009). Öğretmenlik mesleği bilgi aktarma ve bilgi vermenin ötesinde, daha fazla nitelik ve yeterlik gerektiren bir meslek olarak karşımıza çıkmaktadır (Çalışkan, 2005). Günümüzde öğretmenlik mesleği, özel uzmanlık bilgisi ve becerisi gerektiren bir meslektir (Şişman, 2006).

Öğretmen, öğrencilerde istendik yönde davranış değişikliği sağlayan profesyonel kişidir (Sönmez, 2004). Yeni nesillerin topluma faydalı hale getirilmesi ve ülkenin ihtiyaç duyduğu yeterliklerde insan gücünün yetiştirilmesi eğitim sisteminin başat değişkeni öğretmenin sorumluluğundadır. Okulun ve ögretmenin görevi çocuğun yetişmesini sağlamak ve onun bazen çevreyle etkileşimi sonucu kazandığ1 eğitsel olmayan tecrübelerini eğitsel yöne çevirmektir (Küçükahmet, 2003). Bunun yanında öğretmen, okul ve sınıf ortamını öğrenciler için uygun, dikkat çekici ve eğlenceli hale getiren, farklı öğretim yöntem ve tekniklerinden yararlanarak öğrencilerin öğrenme deneyimlerini düzenleyen, onların öğrenme deneyimlerine atılmalarına rehberlik eden ve istenilen davranışların değerlendirmelerini yapan bir öğretim öğesidir (Ada ve Küçükali, 2009). 1739 sayılı Milli Eğitim Temel Kanunu'nun 43. maddesine göre öğretmenlik "Devletin eğitim, öğretim ve bununla ilgili yönetim görevlerini üzerine alan özel bir ihtisas mesleğidir. Öğretmenler bu görevlerini Türk Milli Eğitiminin amaçlarına ve temel ilkelerine uygun olarak ifa etmekle yükümlüdürler” (MEB, 1973) şeklinde ifade edilmektedir. Öğretmenlik mesleği denince; bu mesleğin tanım ve kapsamı, mesleği icra edenlerin görev ve sorumlulukları ile toplumun öğretmenlerden beklentileri kadar, bu mesleğin zihinlerde şekillenen imajı da akla gelmektedir.

İmaj, kişinin bir diğeri (kişiler, kurumlar, meslekler, sivil toplum örgütleri, gruplar, devletler vb.) hakkında yargıda bulunma süreci (Ünsal, 2015), herhangi bir birey, kurum ya da durumun bireyde ve toplumda uyandırdığı etki ile bütünleşen karşılığı (Bektaş, 2010), bir kişi, kurum, marka, obje ya da düşüncenin zihinlerde isteyerek ya da istemeyerek bırakmış olduğu düşünce ya da izlenimler (Özdemirci, 
2012), bireyin zihninde oluşan bir imge (Dinçer, 2001) şeklinde tanımlanmaktadır. Gerek kişiler, gerekse de özel ve kamu kurumları için vazgeçilmez ve yönetilmesi gereken bir olgu olan imaj kavramına araştırmacılar tarafından farklı anlamlar yüklenmiştir. Bazı araştırmacılar konuya olumlu yaklaşırken, bazıları da imajın gerçeğin reddi, değiştirme ve saptırma olduğu şeklinde açıklamaktadır (Geçikli, 2012). Bilgi taşıyıcı olarak tanımlanabilen imaj, bireylerin sahip olduğu bilgilerin önemli bir kısmını sağlar. Dolayisıyla bireyler ve kurumlar ister istemez insanlarda bir imaj oluştururlar (Özüpek, 2005). Herkesin, her nesnenin, çeşitli kurum ve kuruluşların istese de istemese de, imaj yaratma konusunda çaba sarf etse de etmese de bir imajı olacaktır (Yavuz, 2006). İmaj; iyi, kötü, alelade olabilir, ancak iyi bir imaj konusundaki dikkat çeken özellik, iyi imajın kazanılmış olmasıdır (Peltekoğlu, 2004). İmaj kavramının bir kişi veya örgütün ortaya koydukları bir mal, ürün ya da hizmet sonucunda iç ve dış çevrelerinde tanınma ve tercih edilir konuma gelmelerinde önemli bir rolü bulunmaktadır (Akbulut, 2015).

Mesleki imaj, bir işgörenin yeterliliğine ve karakterine ilişkin müşteriler, patronlar, üstler, astlar ve meslektaşlar gibi temel ilgili kişilerin algılarının toplamıdır (Roberts, 2005). İnsanlar bir mesleğin imajıyla ilgili değerlendirme yaparken, o mesleği icra edenlerin görünüşleri, davranışları, konuşmaları, beden dilleri, giyim-kuşamları, başarıları vasıtasıyla gönderdikleri mesajları göz önünde bulundururlar. Bu mesajlar mesleki imajı oluşturmaktadır (Bağçeci, Çetin ve Ünsal, 2013). Öğretmenlik mesleğinin, yeni nesillerin ülkenin refah ve kalkınmasına katkıda bulunacak nitelikli bireyler olarak yetiştirilmesi doğrultusunda önemli sorumlulukları bulunmaktadır. Celep'e (2010) göre, toplumsal yaşamda önemli sayılan görevleri icra eden meslekler daha değerli ve saygın meslekler olmaktadır. Toplumlara ve kültürlere göre statü ve saygınlığı değişen öğretmenlik mesleği, doğrudan insanla ilişkili olmasından dolayı sadece bir kazanç kapısı olarak değil, aynı zamanda kutsal bir meslek olarak da görülmektedir. Türk eğitim tarihinde bilge kişilere ve öğretmenlere saygı duyulmuş, öğretmen denince toplumda davranış modeli, örnek insan anlaşılmıştır (Şişman, 2006). Türkiye'de cumhuriyetin ilk yıllarında Osmanlı geleneği ve devletçi yapısı sayesinde saygın meslekler arasında bulunan öğretmenlik mesleği, saygınlığını 1970'li yıllara kadar devam ettirmiş, sonraları ülkemizdeki hızlı toplumsal değişim ve sanayileşme ile birlikte bu saygınlıkta gerileme olmuştur. Ancak 2000'li yıllarda yaşanan ekonomik krizin özel sektörde çalışanları işten çıkarma ve çalışanların maaşını düşürme şeklindeki yansımaları sonucu yüksek iş güvencesi olan devlet memurluğu, ve dolayısıyla öğretmenlik mesleği değerli hale gelmiştir. Bununla birlikte öğretmenlerin devlette istihdamlarının daha kolay olması ve eğitime yönelik olumlu adımlar da öğretmenliği değerli kılan diğer unsurlar olmuştur (Erden, 2017). Öğretmenlik mesleği, daha çok zihinsel etkinlikleri içermesi ve uzun sayılabilecek bir öğrenim süresi sonunda elde edilmesine karşın aynı konumdaki diğer mesleklere oranla daha az gelir sağlayan bir meslek konumundadır (Celep, 2004). Öğretmenliğin; doktorluk, avukatlık, mühendislik gibi gelir düzeyi yüksek mesleklerle ekonomik getirisi bakımından kıyaslandığında düşük statülü bir meslek olduğu söylenebilir (Gönülaçar, 2016). Öğretmenlik mesleğini icra edenlerin sayısının fazla olması devletin öğretmenlere ekonomik olarak fazla katkı sağlamasını zorlaştırmaktadır (Ergun, Ergezer, Çevik ve Özdaş, 1999).

Bugün Türkiye'de öğretmenlik mesleği statüsü düşük meslek grupları arasında yer almaktadır. Bu durumun sebepleri olarak öğretmenlerin gelir düzeyinin düşüklüğü, öğretmenlerin yaptığı işin birçok kişi tarafından sıradan ve herkesin yapabileceği bir iş olarak değerlendirilmesi ve tarih boyunca çeşitli nedenlerden öğretmenlik için gerekli niteliklerden yoksun insanların, gerek meslek içerisinden gerekse de dışarıdan öğretmenlik mesleğine girmeleri sayılabilir (Eskicumal1, 2004). Türkiye'de öğretmenlik mesleğinin statüsünün giderek azalmasında özellikle Cumhuriyet'in ilk dönemlerinde Atatürk'ün özel ilgisi ile öğretmenlere verilen önemin artık verilmiyor olması ve genel anlamda ülkedeki ekonomik işleyişin sağlıklı ve adil olmaması rol oynamaktadır (Aslan, Aslan ve Cansever, 2012). Öğretmenlerin gelir düzeyinin düşük olması, eğitim hizmeti verdikleri kesimin yaş ve bilgi düzeyinin az olması gibi hususlar öğretmenlerin mesleki statüsünü düşürmektedir (Erden, 2017). Eğitim fakültesi mezunu öğretmenlerin çalışma yaşamına katılmasında yaşanan sıkıntılar ile öğretmenlik mesleğinin statik ve oldukça sınırlı bir kariyer ilerlemesine izin veren yapısı da öğretmenlik mesleğinin toplumsal statüsünü belirleyen diğer etkenlerdir (Güven, 2010). Aynı zamanda öğretmenlerin mesleki özerkliklerinin olmaması da öğretmenlik mesleğinin statüsünü olumsuz yönde etkileyen bir diğer faktör olmaktadır. Özellikle eğitim-öğretim ve program boyutunda öğretmenlerin mesleki özerkliklerinin olmadığı; onların programa yönelik olarak sadece uygulayıcı rolünde bulundukları görülmektedir (Göker ve Gündüz, 2017). Türkiye'de öğretmenlerin bir kısmı, ekonomik durumunun ve sosyal statüsünün yüksek olmaması nedeniyle ya yüksek maaşlı ve yüksek statülü farklı mesleklere geçmekte ya da mesleklerinin sunmuş olduğu boş zamanlardan yararlanarak ek işler yapmaktadır. Bu durum hem öğretmenlik mesleğinin saygınlığını düşürmekte hem de eğitimin kalitesini azaltmaktadır (Çeliköz, 2004). 
Devlet Personel Başkanlığı'nın Mart 2018 verilerine göre Türkiye'de istihdam edilen kamu çalışanı sayısı 3.129.304'tür (DPB, 2018). Milli Eğitim Bakanlığı verilerine göre ise bakanlık bünyesinde 1.030.130 öğretmen görev yapmaktadır (MEB, 2018). Bu verilerden hareketle Türkiye'de öğretmenlerin kamu çalışanları arasında büyük bir istihdam oranıyla temsil edildikleri söylenebilir. Öğretmenlerin kamuda çalışan büyük bir kesimi oluşturmaları ve onlardan çeşitli beklentilerin olması öğretmenlik mesleğinin önemini artırmaktadır. Öğretmenler, toplumlarda gerek rol model olmalarıyla gerekse de nitelikli bireyleri yetiştirme sorumluğunu taşımalarıyla toplumsal kalkınmada da öncelikli göreve sahip olmuşlardır (MEB, 2017a). Bu denli önemli bir sorumluğu üstelenen öğretmenlik mesleğinin buna paralel olarak nasıl algılandığı sorusu araştırmanın temel motivasyonunu oluşturmaktadır. Özellikle öğretmenlik mesleğini icra edenler tarafından bu mesleğin nasıl algılandığı konusu öğretmenlik mesleğine bir iç bakış sağlaması bakımından araştırmacılar tarafından önemli görülmüştür.

$\mathrm{Bu}$ araştırmanın amacı, Elazı̆̆ ilindeki ilkokul, ortaokul ve liselerde görev yapan öğretmenlerin "öğretmenlik mesleğinin imajı" hakkındaki görüşlerini belirlemektir. Yeni nesillerin yetiştirilmesi görev ve sorumluluğunu üstelenen öğretmenlik mesleğinin bu mesleği icra edenler tarafindan nasıl algılandığ1 konusu önem arz etmektedir. Bu genel amaç çerçevesinde aşağıdaki sorulara cevap aranmıştır:

1. Öğretmenler mesleki imajları hakkında neler düşünmektedirler?

2. Öğretmenler günümüzdeki mesleki imajlarını geçmişteki mesleki imajları ile kıyasladıklarında nasıl değerlendirmektedirler?

3. Öğretmenlik mesleğinin imajını daha iyi hale getirmek için neler yapılabilir?

\section{YÖNTEM}

$\mathrm{Bu}$ araştırma, sosyal fenomenleri, insan davranışlarını ve bu davranışların sebeplerinin neler olduğunu detaylı ve derin bir şekilde anlamayı amaçlayan nitel araştırma yöntemleri (Güler, Halıcıoğlu ve Taşğın, 2013) arasında yer alan olgu bilim (fenomenoloji) deseninde gerçekleştirilmiştir. Fenomenolojik çalışma birkaç kişinin bir fenomen veya kavramla ilgili yaşanmış deneyimlerinin ortak anlamını tanımlamaktadır (Creswell, 2013). Birçok alanda (dinden sanata, sosyolojiden psikolojiye kadar) uygulanan fenomenoloji deseninin mantı̆̆ anlamaktır (Bal, 2016).

\section{Çalışma Grubu}

Araştırmanın çalışma grubunu 2017-2018 eğitim öğretim yılında Elazığ ilindeki ilkokul, ortaokul ve liselerde görev yapan öğretmenler oluşturmaktadır. Tamamıyla ön görüşmeler yapılmış, görüşlerini belirtmekten kaçınmayacaklarını belirten 40 öğretmene rastgele örnekleme yöntemiyle ulaşılmıştır. Çalışma grubunda yer alan katılımcıların demografik bilgileri Tablo 1'de yer almaktadır:

Tablo 1. Katılımcıların demografik özellikleri

\begin{tabular}{|c|c|c|}
\hline Demografik özellikler & & $\mathbf{f}$ \\
\hline \multirow{2}{*}{ Cinsiyet } & Kadın & 13 \\
\hline & Erkek & 27 \\
\hline \multirow{3}{*}{ Görev yapılan okul türü } & İlkokul & 11 \\
\hline & Ortaokul & 22 \\
\hline & Lise & 7 \\
\hline \multirow{5}{*}{ Mesleki Kıdem } & $1-5 \mathrm{y} 1 \mathrm{l}$ & 11 \\
\hline & $6-10$ yil & 9 \\
\hline & $11-15$ y1l & 10 \\
\hline & $16-20$ y1l & 6 \\
\hline & $21 \mathrm{y} 11+$ & 4 \\
\hline \multirow{7}{*}{ Yaş } & $20-25$ yaş & 3 \\
\hline & 26-30 yaş & 11 \\
\hline & $31-35$ yaş & 8 \\
\hline & $36-40$ yaş & 10 \\
\hline & 41-45 yaş & 4 \\
\hline & 46-50 yaş & 1 \\
\hline & 50 yaş + & 3 \\
\hline Toplam & & 40 \\
\hline
\end{tabular}




\section{Verilerin Toplanması}

Araştırma verileri, araştırmacılar tarafindan geliştirilen ve açık uçlu sorulardan oluşan yarı yapılandırılmış görüşme formu ile elde edilmiştir. Yarı yapılandırılmış görüşmede sorular açık uçlu olmakta, görüşme kılavuzu takip edilerek yöneltilmekte ve sorular bir sistematik ve yapı çerçevesinde sorulmaktadır (Demir, 2009). Görüşme formu hazırlama aşamasında ilgili alan yazın taranmış, bu konuda eğitim bilimleri alanında bulunan uzman kişiden görüş alınmıştır. Uzman görüşünden sonra öğretmenlerin "öğretmenlik mesleğinin imajı" hakkındaki görüşlerini belirlemeyi amaçlayan dört soruluk yarı yapılandırılmış görüşme formu hazırlanmıştır. Araştırma verileri araştırmacılar tarafından okulların ziyaret edilip formaların dağıtılması suretiyle elde edilmiştir. Görüşme formunda şu sorular yer almaktadır:

1. Öğretmenlerin mesleki imajı hakkında neler düşünüyorsunuz?

2. Öğretmenlerin günümüzdeki mesleki imajını geçmişteki mesleki imajı ile kıyasladığınızda nasil değerlendirirsiniz?

3. Mesleki imajlarına katkı sağlamada, öğretmenlerin yapması gerekenler nelerdir?

4. Öğretmenlerin mesleki imajına katkı sağlamada, Milli Eğitim Bakanlı̆̆ı’nın (MEB) ve siyasilerin yapması gerekenler nelerdir?

\section{Verilerin Analizi}

Araştırmada katılımcılardan elde edilen verilerin analizi için içerik analizi yöntemi kullanılmıştır. Yazılan ve söylenenin, hazırlanan açıklayıcı yönergeye göre ne kadar sıklıkla söylendiğinin bulunması olan içerik analizi (Aziz, 2011); söylemin görünen, kolayca yakalanan, sergilenmiş ve ilk bakışta algılanan içeriği yerine, gizil, üstü örtülü içeriğini ortaya çıkarmayı sağlamaktadır. Dolayısıyla içerik analizi, mesajda, bireyi görünmeden etkileyen öğelerin belirlenmesine yönelik "ikinci bir okuma"dır (Bilgin, 2006).

Araştırmada öncelikle veriler K1, K2, K3, .. ,K40 şeklinde kodlanarak dijital ortama aktarılmıştır. Her bir görüşme formunda verilen katılımcı görüşleri benzerlik düzeyine göre kodlanarak, birbirine yakın olan kodlar alt temalara yerleştirilmiştir. Araştırmanın geçerliği ve güvenirliğini belirlemek için izlenen yol aşağıda izah edilmiştir.

Araştırmada geçerliğin sağlanması için çalışma sürecinin başından sonuna kadar araştırmacılar arasında fikir birliği sağlanmış, uyuşmazlık durumlarında ortak noktada buluşmak için gerekli görüşmeler yapılmıştır. Araştırmanın güvenirliğini belirlemek için Miles ve Huberman'ın (1994) “Uzlaşma Yüzdesi $(P)$ = Görüş Birliği / (Görüş Birliği + Görüş Ayrılı̆̆g) x 100" formülü kullanılmıştır. Katılımcı görüşlerinin yerleştirildiği temalara uyumlu olup olmadıklarını belirlemek üzere eğitim bilimleri alanında uzman olan kişinin görüşüne başvurulmuş, uzmandan bütün katılımcı görüşlerini araştırmacılar tarafından belirlenen temalara yerleştirmesi istenmiştir. Bu işlem sonrasında katılımcıların ileri sürdüğü 168 görüşten 14 görüşün, uzman tarafindan farklı temalara yerleştirildiği belirlenmiştir. "Uzlaşma Yüzdesi” formülüne göre bu araştırmanın güvenirliği $\sim \% 92$ olarak belirlenmiştir. Nitel araştırmalar için uzlaşma yüzdesi formülünden elde edilen değerin \%70 ve üzerinde olması (Miles ve Huberman, 1994), araştırmanın güvenilir olduğunu gösterdiğinden, bu araştırmanın yeterli düzeyde güvenilir olduğu belirlenmiştir.

\section{BULGULAR}

$\mathrm{Bu}$ bölümde katılımcıların ifade ettikleri görüşler, araştırmanın amaçları doğrultusunda analiz edilerek sunulmuş, bulgular tablolar ve şekillerle açıklanmıştır.

Katılımcılara yöneltilen “Öğretmenlerin mesleki imajı hakkında neler düşünüyorsunuz?" sorusuna vermiş̧ oldukları yanıtlardan elde edilen bulgular Tablo 2'de sunulmuştur.

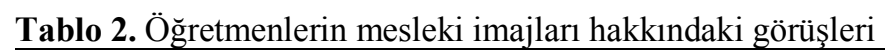

\begin{tabular}{lll}
\hline & \multicolumn{1}{l}{ Temalar } & $\mathbf{f}$ \\
\cline { 2 - 3 } Öğretmenlerin mesleki imajları hakkındaki görüsşleri & Olumlu görüş belirtenler & 7 \\
\cline { 2 - 3 } & Olumsuz görüş belirtenler & 33 \\
\cline { 2 - 3 } & Toplam & 40 \\
\hline
\end{tabular}

Tablo 2'de öğretmenlerin mesleki imajları hakkında yöneltilen soruya verdikleri yanıtlar incelendiğinde 7 öğretmenin mesleki imajları hakkında olumlu (Kadın: 4, Erkek: 3), 33 öğretmenin ise mesleki imajları hakkında olumsuz (Kadın: 9, Erkek: 24) görüşe sahip olduğu belirlenmiştir. 
Mesleki imajları hakkında olumlu görüş belirten öğretmenler bunu; öğretmenliğin her dönem saygın bir meslek olarak görülmesi, öğretmenlerin gelecek nesilleri yetiştirmelerindeki rolü ve onların topluma örnek olmaları gibi unsurlarla ifade etmişlerdir. Olumlu görüş belirten bazı öğretmenlerin görüşleri aşağıda yer almaktadır:

K23: "Öğretmenlik asla yeri doldurulamaz bir meslektir. Veli ile bu kadar karşı karşıya kalınmasa gayet saygın bir meslek” (Kadın, İlkokul, Mesleki Kıdem:1-5 yıl, Yaş: 31-35 yaş).

K28: "Öğretmen topluma model olan kişidir ve ögretmenlik her dönem değerli bir meslek olarak kabul edilmiştir" (Erkek, Ortaokul, Mesleki Kıdem:16-20 y1l, Yaş: 41-45 yaş).

K38: "Öğretmenlik bu toplumdaki en saygın ve en kutsal meslektir. Gelecek kuşakları yetiştiren ulvi bir meslektir” (Kadın, Ortaokul, Mesleki Kıdem:1-5 yıl, Yaş: 20-25 yaş).

Mesleki imajları hakkında olumsuz görüş belirten öğretmenler, mesleki imajın öğretmenlerin hal ve hareketlerinden, toplumun bakış açısından ve siyasilerin yaklaşımından olumsuz yönde etkilendiğini belirtmişlerdir. Öğretmenlerin mesleki imajlarını olumsuz olarak algılamalarında; öğretmen eğitiminin yetersizliği, öğretmenlerin iletişim, giyim-kuşam ve davranış noktalarındaki eksiklikleri, velilerin ve öğrencilerin öğretmenlere olan olumsuz yaklaşımları, mevcut öğretmen şikâyet hatları, öğretmenlere değer verilmemesi, onlara danışılmaması, öğretmenlerin öğrenciler üzerinde etkilerinin olmaması, düşük maaş alındığı düşüncesi, öğretmenliğin kolay ve tatillerle anılan bir meslek olarak algılanması gibi ifadeler öne çıkmaktadır. Olumsuz görüş belirten bazı öğretmenlerin görüşleri şu şekildedir:

K8: "Toplumda saygınlı̆̆ yok denecek kadar az. Öğretmenliğin statüsü çok çok altlara çekildi. Fakültelerde verilen eğitim ögretmen yeterlilikleri için eksik. Iletişim becerisi kötü birçok kişi ögretmenlik yapıyor. Kılık klyafet serbestliğinden sonra mahalle bakkalı, şoför gibi dolanan bir sürü ögretmen var" (Kadın, İlkokul, Mesleki Kıdem:11-15 y1l, Yaş: 3135 yaş).

K19: “Öğretmenlerin kesinlikle okullarda bir itibarı kalmamıştır. Öğrenciler üzerinde etkisi kalmamıştır. Öğrenciler öğretmen üzerinde etki kurmuşlardır” (Erkek, Ortaokul, Mesleki Kıdem: 6-10 yıl, Yaş: 31-35 yaş).

K25: "Öğretmenlerin toplum açısından imajları pek iç açıcı değildir. Bu imajın yaratılmasında öğretmenlerin kendi hal ve hareketleri ile çevrenin ögrretmene baklş açısı etkili olmuştur" (Kadın, Lise, Mesleki Kıdem:11-15 yıl, Yaş: 41-45 yaş).

K26: "Türkiye'de öğretmenlik "ayă̆a düşmüş" seviyede. Toplumda bir saygınlı̆̆l yok. Siyasilerin "ögretmenlerin üç ay tatili var” dediği bir ülkede toplumdan bu saygınlı̆̆ beklemek de yanlış olur" (Erkek, Ortaokul, Mesleki K1dem:16-20 y1l, Yaş: 41-45 yaş).

K33: "Günümüzde ögretmenlerin mesleki imajı yok denecek kadar azalmıştır. Her alanda bilgisine, fikrine danışılan, saygl gösterilen bir meslek iken, şimdi değer görmeyen, hiçbir şey olamazsan ögretmen ol noktasina getirilen bir noktaya gelmiştir. Buna sebep biraz bakanlık ve ögretmenlerin kendi davranışlarıdır" (Kadın, Ortaokul, Mesleki Kıdem:1115 yıl, Yaş: $31-35$ yaş).

K34: "Öğretmen imajının zayıf olduğunu düşünüyorum. Çünkü toplumda hiç bir şey olamazsan bari öğretmen ol fikri hâkim” (Erkek, Ortaokul, Mesleki Kıdem:11-15 yıl, Yaş: 36-40 yaş).

K36: "Ögretmenlerin mesleki imajının elindeki firsatlar ve maddi imkânlarının azalarak itibarının oldukça düşürüldüğünü düşünüyorum. En basit haliyle veliler kolayca bir telefon hattıyla öğretmeni şikâyet edebiliyorken ögretmenin elinde kendisine yapılan haksızlı̆̆ çözebileceği hiçbir yol yok” (Kadın, İlkokul, Mesleki Kıdem:1-5 yıl, Yaş: 26-30 yaş).

Katılımcılara yöneltilen "Öğretmenlerin günümüzdeki mesleki imajını geçmişteki mesleki imajı ile kıyasladığınızda nasıl değerlendirirsiniz?” sorusuna vermiş oldukları yanıtlardan elde edilen bulgular Tablo 3'te sunulmuştur. 
Tablo 3. Öğretmenlerin mesleki imajlarının geçmişteki mesleki imajlarına göre durumu

\begin{tabular}{lll}
\hline \multirow{2}{*}{$\begin{array}{l}\text { Öğretmenlerin mesleki imajlarının geçmişteki mesleki } \\
\text { imajlarına göre durumu hakkındaki görüşleri }\end{array}$} & Temalar & $\mathbf{f}$ \\
\cline { 2 - 3 } & Aynı durumdadır & 3 \\
\cline { 2 - 3 } & Daha kötü durumdadır & 37 \\
\cline { 2 - 3 } & Toplam & 40 \\
\hline
\end{tabular}

Tablo 3’te öğretmenlerin mesleki imajlarının geçmişteki mesleki imajlarıyla karşılaştırılması hakkında yöneltilen soruya verdikleri yanıtlar incelendiğinde üç öğretmenin mesleki imajlarının geçmişle aynı durumda olduğu, 37'sinin ise mesleki imajlarının geçmişe oranla daha kötü durumda olduğu görüşüne sahip olduğu görülmektedir. Mesleki imajlarının geçmişe oranla daha kötü durumda olduğu belirten öğretmenler; bunu toplumun bakışı, öğretmen seçme ve atamasında yapılan yanlışlıklar, mesleki yetersizlik, öğretmen adaylarının atanmasında yaşanan güçlükler, öğretmenliğin kolay bir meslek olarak algılanması, öğretmenliğin sadece bir iş olarak görülmesi, bilgiye ulaşmanın getirdiği kolaylıkla birlikte öğretmenin öneminin azalması, öğretmene geçmişe oranla daha az saygı gösterilip daha az değer verilmesi, düşüncelerinin önemsenmemesi ve öğretmenlerin geçmişe oranla daha az fedakarlık yapmalarıyla ifade etmişlerdir. Mesleki imajlarının geçmişe göre daha kötü durumda olduğunu ve mesleği imajlarının geçmişe göre aynı durumda olduğunu belirten bazı öğretmenlerin görüşleri şu şekildedir:

K1: “Önceden ögrretmen denilince önünde sayglyla ĕgilecek kimse akla geliyordu. (En azından söylenilenler ve anlatılanlar bu yönde). Ancak bu durum biraz değişmiş durumda diye düşünüyorum. Artık günümüzde bilgiye vs. ulaşmak kolaylaştığ iç̧in ögrretmenin önemi de azaldı ve ögretmen denilince duyulan o saygl ve itaat de önemini yitirmeye başladı" (Erkek, Ortaokul, Mesleki Kidem:1-5 yı1, Yaş: 20-25 yaş).

K11: "Günümüzdeki öğretmenler geçmişteki meslektaşlarına göre daha olumsuz denebilecek bir imaja sahipler. Sebepleri ise; halkın genel bakış açısı, mesleki yetersizlik, ögretmen seçme ve atamasında yapılan yanlışlıklar”, (Kadın, Ortaokul, Mesleki Kıdem:1115 y1l, Yaş: $36-40$ yaş).

K24: "Geçmişte saygın, düşünceleri önemsenen, "eti de kemiği de senin” düşüncesiyle ögrenci emanet edilen bir meslekti. Şimdi bunlardan eser yok. Eğitim sistemindeki değişiklikler de bu kötü değişimin müsebbibi” (Kadın, Lise, Mesleki Kıdem:11-15 yıl, Yaş: 36-40 yaş).

K35: "Geçmişte daha saygın, toplum tarafindan üstün insan olarak görülür iken bugün sıradan, basit ve herhangi bir memurluk gibi görülmektedir” (Erkek, Lise, Mesleki Kıdem: 6-10 yıl, Yaş: 36-40 yaş).

K36: "Üniversite mezunlarının atanma durumunun az olmasl gibi sebeplerin de büyük etkisiyle mesleki imaj toplumun en alt düzeyindedir" (Kadın, İlkokul, Mesleki Kıdem:1-5 yıl, Yaş: 26-30 yaş).

K38: “Öğretmenliğin günümüz şartlarında ayaklar altına alındığını düşünüyorum. Veli ve ögrencilerin baş tacı edildiğini, ancak öğretmenlik mesleğinin itibarının düşürüldüğünü düşünüyorum” (Kadın, Ortaokul, Mesleki Kıdem:1-5 yıl, Yaş: 20-25 yaş).

K39: "Günün şartlarında bilgiye kolay ulaşıldığı için öğretmenin statüsü ve imajı değişmiştir. Algl da bu oranda değişmiştir. Geçmiş̧e fedakar, otorite, her şey için danışılan rollerini taşıyan ögretmen günümüzde mesleğini iş olarak yapmaktadır" (Erkek, Lise, Mesleki Kıdem: 16-20 yıl, Yaş: $41-45$ yaş ).

K28: “Mesleki imajın aynı olduğunu düşünüyorum” (Erkek, Ortaokul, Mesleki Kıdem: 16-20 yı1, Yaş: 41-45 yaş).

Katılımcılara yöneltilen "Mesleki imajlarına katkı sağlamada öğretmenlerin yapması gerekenler nelerdir?" sorusuna verilen yanıtların analizi ile elde edilen bulgular ışığında oluşturulan alt temalar Şekil 1'de sunulmuştur. 


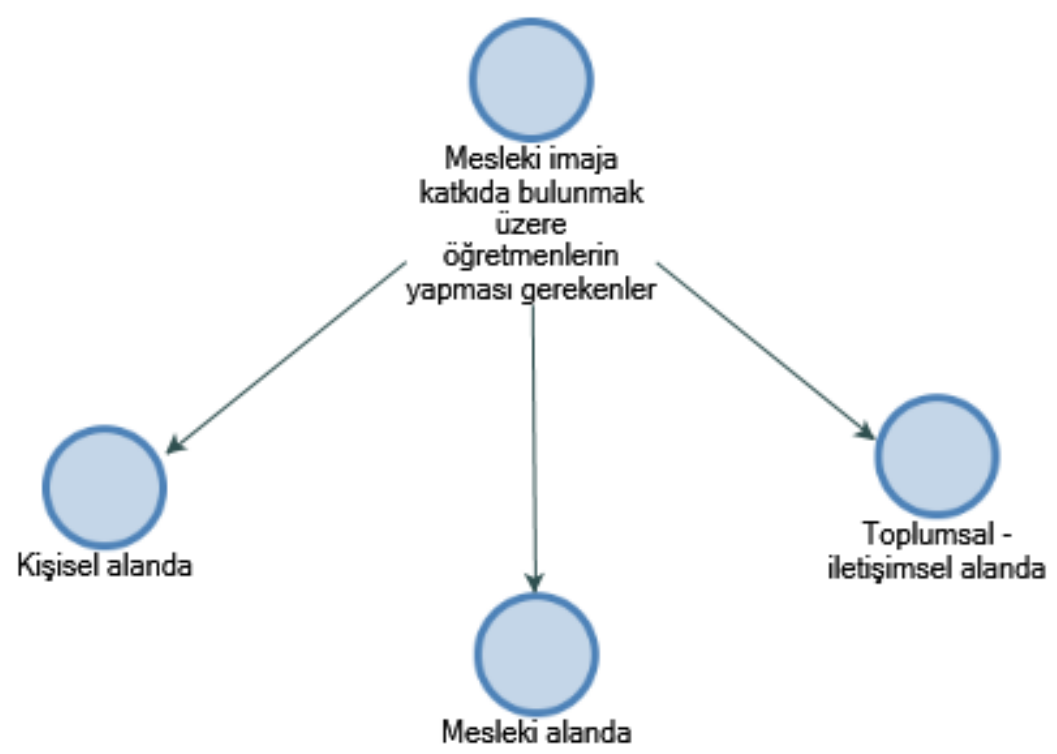

Şekil 1. Mesleki imajlarına katkıda bulunmak üzere öğretmenlerin yapması gerekenler

Mesleki imajlarına katkıda bulunmak üzere öğretmenlerin yapması gerekenler; kişisel alanda yapılması gerekenler $(n=12)$, mesleki alanda yapılması gerekenler $(n=39)$ ve toplumsal-iletişimsel alanda yapılması gerekenler $(n=32)$ olmak üzere üç alt tema altında değerlendirilmiştir.

Mesleki imajlarına katkıda bulunmak üzere öğretmenlerin kişisel alanda yapması gerekenler Şekil 2'de sunulmuştur.

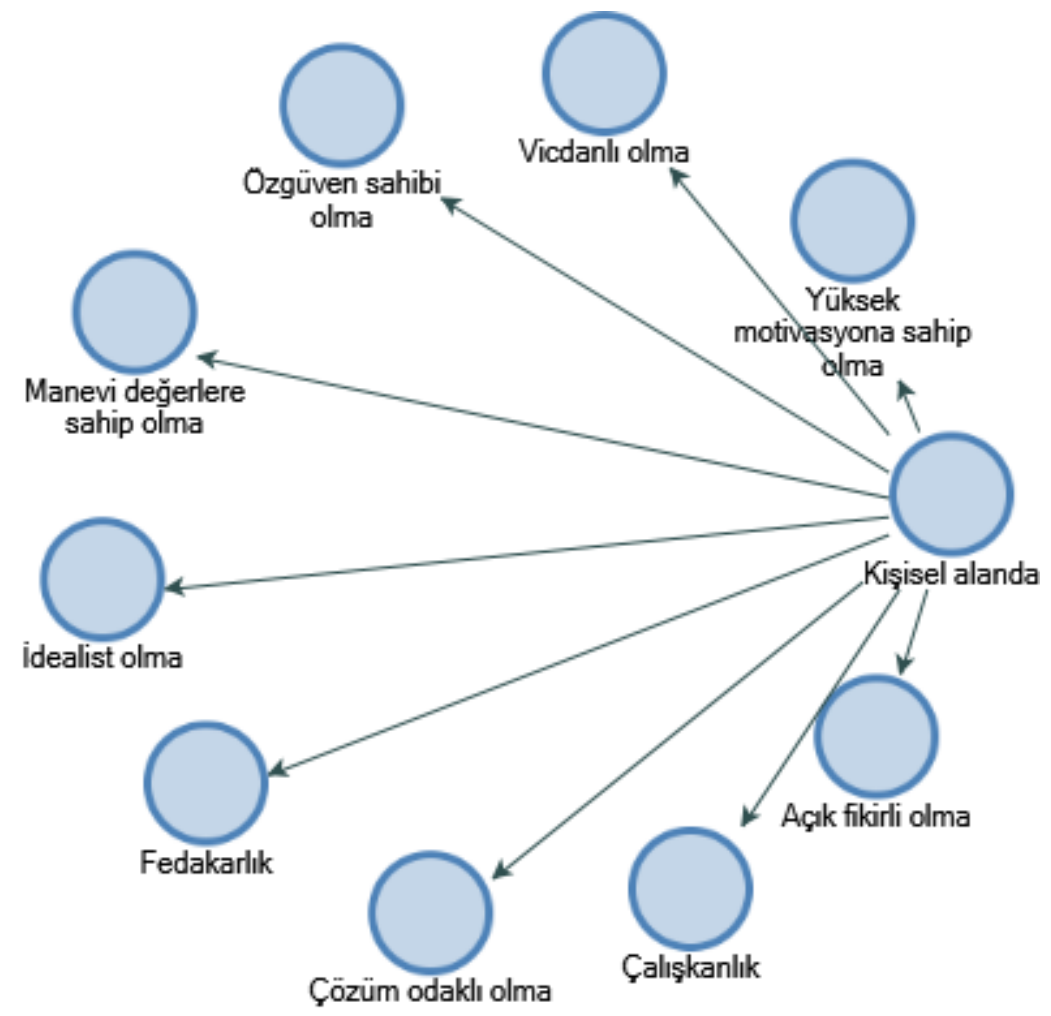

Şekil 2. Mesleki imajlarına katkıda bulunmak üzere öğretmenlerin kişisel alanda yapması gerekenler

Mesleki imajlarına katkıda bulunmak üzere öğretmenlerin kişisel alanda yapması gerekenler alt temasına ilişkin öğretmen görüşleri; yüksek motivasyona sahip olma $(n=1)$, vicdanlı olma $(n=1)$, özgüven sahibi olma $(n=1)$, manevi değerlere sahip olma $(n=1)$, idealist olma $(n=1)$, fedakarlık $(n=3)$, çözüm odaklı olma ( $\mathrm{n}=2)$, çalışkanlık $(\mathrm{n}=1)$ ve açık fikirli olma $(\mathrm{n}=1)$ ifadeleri olarak ortaya çıkmıştır. Öğretmen görüşleri arasında en fazla ifade edilen görüşler ise fedakarlık $(n=3)$ ve çözüm odaklı olma $(n=2)$ ifadeleridir. Mesleki 
imajlarına katkıda bulunmak üzere öğretmenlerin kişisel alanda yapması gerekenler alt temasına ilişkin bazı öğretmenlerin görüşleri şu şekildedir:

K2: "Mesleğini sevmeli, gerekeni yapacak fedakarlı̆̆l gösterebilmelidir” (Erkek, Ortaokul, Mesleki Kıdem: 26 yıl+, Yaş: 50 yaş + ).

K8: "Her öğretmen vicdan çerçevesinde her çocuğu kendi evladı gibi görerek, yanlış her türlü davranıştan kaçınarak davranmalı" (Kadın, Illkokul, Mesleki Kıdem: 11-15 yıl, Yaş: 31-35 yaş).

K31: "Tüm sistemsel sorunlara rağmen motivasyonlarını en üst düzeyde tutmalılar" (Erkek, Ortaokul, Mesleki Kıdem: 1-5 yıl, Yaş: 26-30 yaş).

K40: "Toplumsal sorunlara çözüm üretebilmeliler" (Erkek, İlkokul, Mesleki Kıdem: 11$15 \mathrm{yll}$, Yaş: $36-40$ yaş).

Mesleki imajlarına katkıda bulunmak üzere öğretmenlerin mesleki alanda yapması gerekenler Şekil 3'te sunulmuştur.

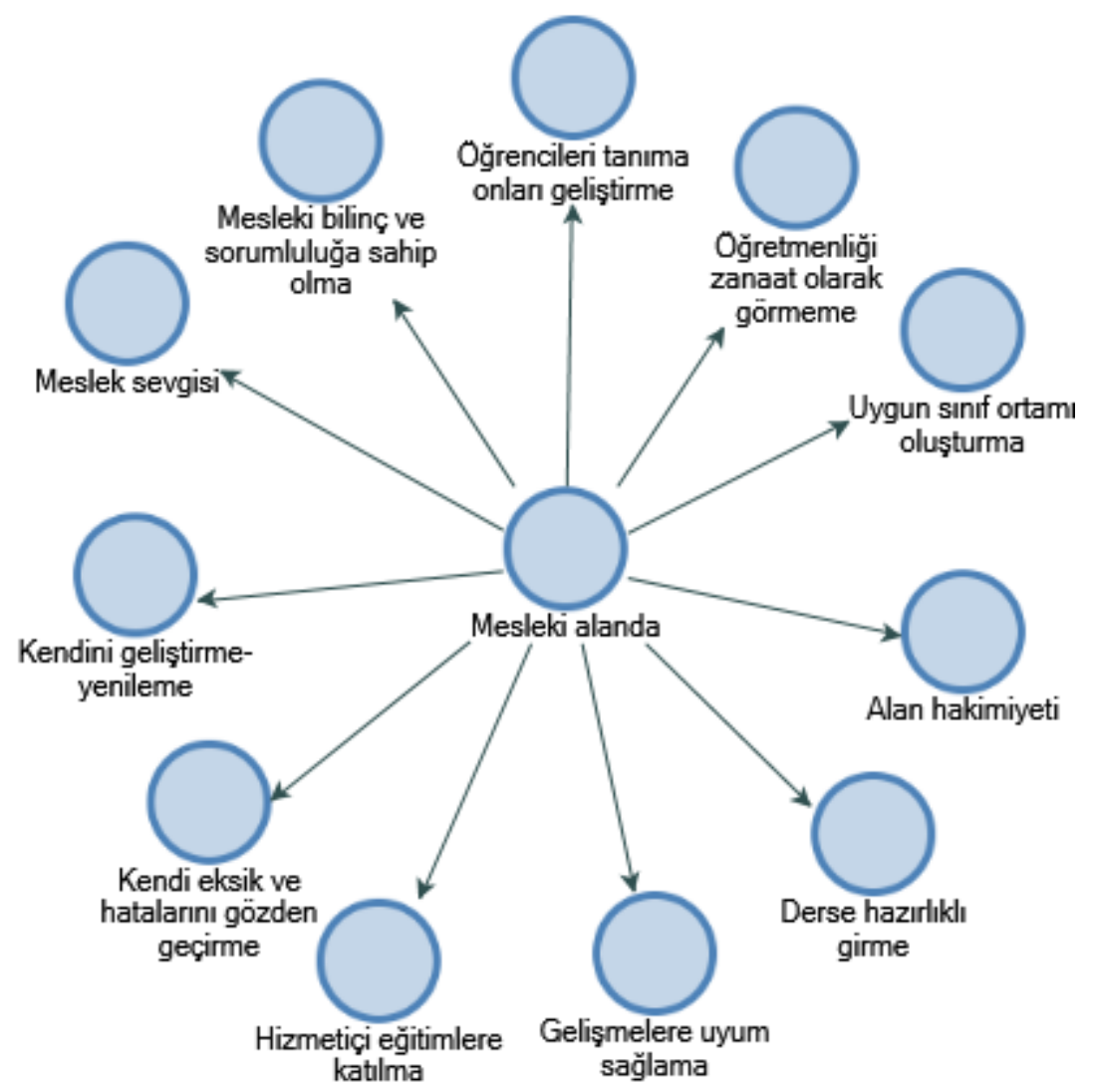

Şekil 3. Mesleki imajlarına katkıda bulunmak üzere öğretmenlerin mesleki alanda yapması gerekenler

Mesleki imajlarına katkıda bulunmak üzere öğretmenlerin mesleki alanda yapması gerekenler alt temasına ilişkin öğretmen görüşleri; öğrencileri tanıma ve onları geliştirme $(n=1)$, öğretmenliği yalnızca zanaat olarak görmeme $(\mathrm{n}=1)$, uygun sınıf ortamları oluşturma $(\mathrm{n}=1)$, alan hakimiyeti $(\mathrm{n}=1)$, derse hazırlıklı girme $(n=3)$, gelişmelere uyum sağlama $(n=3)$, hizmet içi eğitimlere katılma $(n=3)$, kendi eksik ve hatalarını gözden geçirme $(n=1)$, kendini geliştirme-yenileme $(n=17)$ ile meslek sevgisi $(n=2)$ ve mesleki bilinç ve sorumluluğa sahip olma $(n=6)$ ifadeleri şeklindedir. Öğretmen görüşleri arasında en fazla kendini geliştirme-yenileme $(n=17)$ ve mesleki bilinç ve sorumluluğa sahip olma $(n=6)$ ifadeleri öne çıkmaktadır. Mesleki imajlarına katkıda bulunmak üzere öğretmenlerin mesleki alanda yapması gerekenler alt temasına ilişkin bazı öğretmenlerin görüşleri şu şekildedir:

K1: "Burada en önemli şey ögretmenin kendini gelişen teknoloji, bilim, sanat vs. alanlarla ilgili güncel tutabilmesi. Yeterliliğe sahip olduğunu yaparak yaşayarak kanttlamasıdır" (Erkek, Ortaokul, Mesleki Kıdem: 1-5 yıl, Yaş: 20-25 yaş).

K5: "Öğretmenliği para kazanılacak bir iş olmaktan öte bir meslek olduğunu benimsemeliler" (Erkek, İlkokul, Mesleki Kıdem: 16-20 yıl, Yaş: 36-40 yaş). 
K10: "Görevlerinin sorumluluğunu hissederek titizlikle çalışmalılar” (Erkek, İlkokul, Mesleki Kıdem: 6-10 y11, Yaş: 36-40 yaş).

K14: "Öğretmenler her şeyden önce kendilerini geliştirmek için, çok kitap okumal, işlerini laylkiyla yapmalı" (Erkek, Lise, Mesleki Kıdem: 26 yıl+, Yaş: 50 yaş+).

K17: "Kendilerini daha etkin yetiştirmeleri ve çok kitap okumaları gerekir. En azından yüksek lisans veya doktora yapmalarını beklerim” (Erkek, Ortaokul, Mesleki Kıdem: 1-5 yıl, Yaş: 26-30 yaş).

Mesleki imajlarına katkıda bulunmak üzere öğretmenlerin toplumsal-iletişimsel alanda yapması gerekenler Şekil 4'te sunulmuştur.

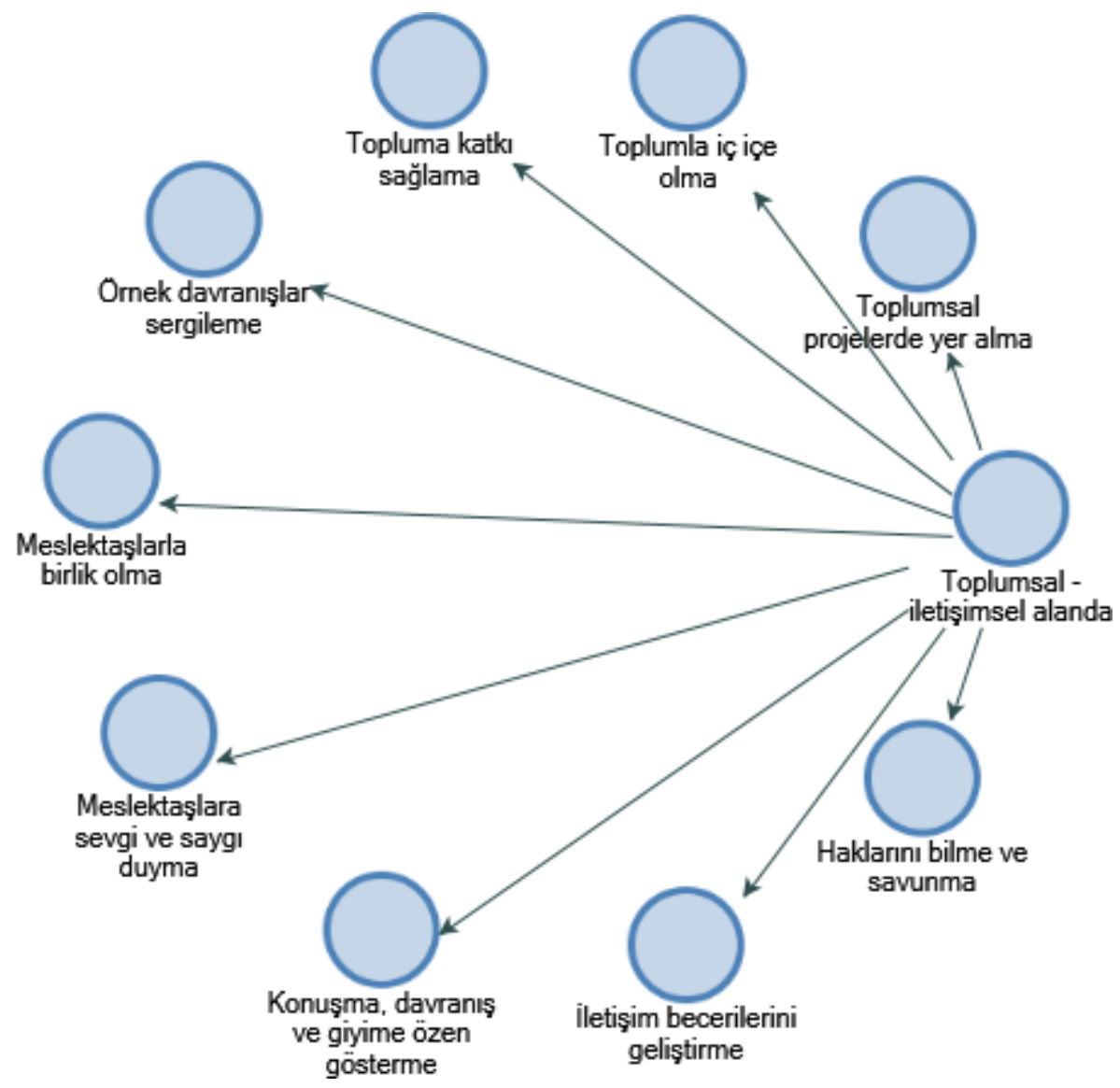

Şekil 4. Mesleki imajlarına katkıda bulunmak üzere öğretmenlerin toplumsal-iletişimsel alanda yapması gerekenler

Mesleki imajlarına katkıda bulunmak üzere öğretmenlerin toplumsal-iletişimsel alanda yapması gerekenler alt temasına ilişkin öğretmen görüşleri; toplumsal projelerde yer alma $(n=1)$, toplumla iç içe olma $(n=4)$, topluma katkı sağlama $(n=1)$, örnek davranışlar sergileme $(n=7)$, meslektaşlarla birlik olma $(n=4)$, meslektaşlara sevgi ve saygı duyma $(n=1)$, konuşma, davranış ve giyimine özen gösterme $(n=6)$, iletişim becerilerini geliştirme $(n=5)$ ve haklarını bilme ve savunma $(n=3)$ ifadeleri olarak ortaya çıkmıştır. Öğretmen görüşleri arasında en fazla ifade edilen görüşler ise örnek davranışlar sergileme $(n=7)$ ve konuşma, davranış ve giyimine özen gösterme $(n=6)$ ifadeleridir. Mesleki imajlarına katkıda bulunmak üzere öğretmenlerin toplumsal-iletişimsel alanda yapması gerekenler alt temasına ilişkin bazı öğretmenlerin görüşleri şu şekildedir:

K9: "Öğretmenler arasında bir birliktelik yok, herkes kendi çıkarları doğrultusunda hareket ediyor. Öncelikle birlik oluşturulmalı” (Erkek, İlkokul, Mesleki Kıdem: 16-20 yıl, Yaş: 36-40 yaş).

K27: "Haklarının savunucusu olmalı ve birlik olarak hareket etmeyi başarmalıdırlar" (Kadın, Ortaokul, Mesleki Kıdem: 6-10 yıl, Yaş: 26-30 yaş). 
K36: "Öğretmen kllık klyafetiyle örnek olmall, konuşmaslyla, diksiyonuyla fark yaratmall, Türkçeyi iyi kullanmalı” (Kadın, İlkokul, Mesleki Kıdem: 1-5 yıl, Yaş: 26-30 yaş).

K40: "Toplumsal sorunlara çözüm üretebilmeli, toplumsal ilişkilerinde pozitif tavır sergilemeye gayret göstermeli ve toplumla sürekli iç içe olmalıdırlar" (Erkek, İlkokul, Mesleki Kıdem: 11-15 yıl, Yaş: 36-40 yaş).

Katılımcılara yöneltilen "Öğretmenlerin mesleki imajına katkı sağlamada MEB ve siyasilerin yapması gerekenler nelerdir?" sorusuna ilişkin öğretmenlerin ileri sürdükleri görüşler üç alt tema altında değerlendirilmiştir. Bunlar; eylemsel alanda yapılması gerekenler $(n=38)$, politik alanda yapılması gerekenler $(n=18)$, ekonomik ve sosyal alanda yapılması gerekenler $(n=17)$ şeklindedir.

Mesleki imaja katkıda bulunmak üzere MEB ve siyasilerin yapması gerekenler Şekil 5'te sunulmuştur.

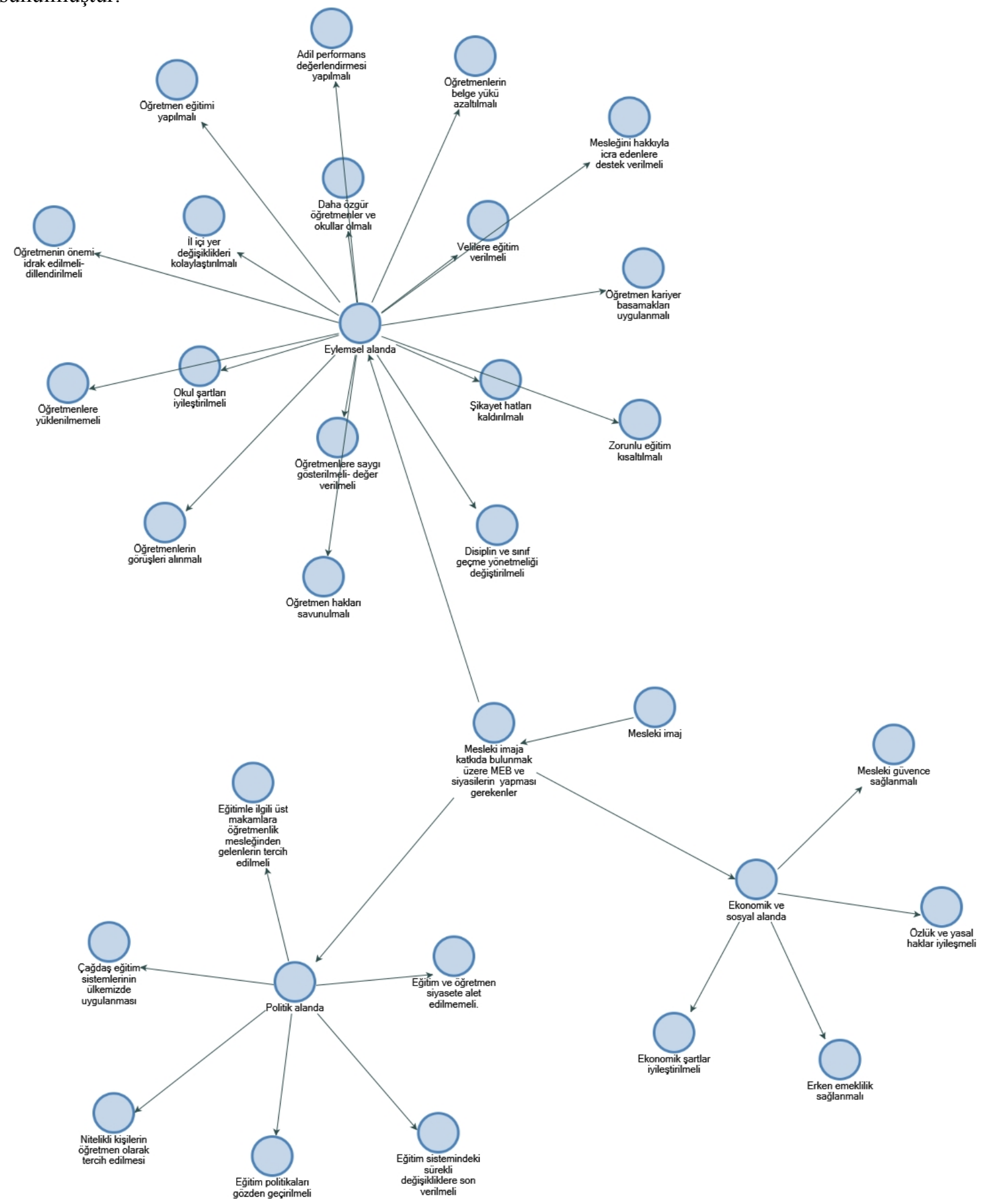


Şekil 5. Mesleki imaja katkıda bulunmak üzere meb ve siyasilerin yapması gerekenler

Mesleki imaja katkıda bulunmak üzere MEB ve siyasilerin eylemsel alanda yapması gerekenler Şekil 6'da sunulmuştur.

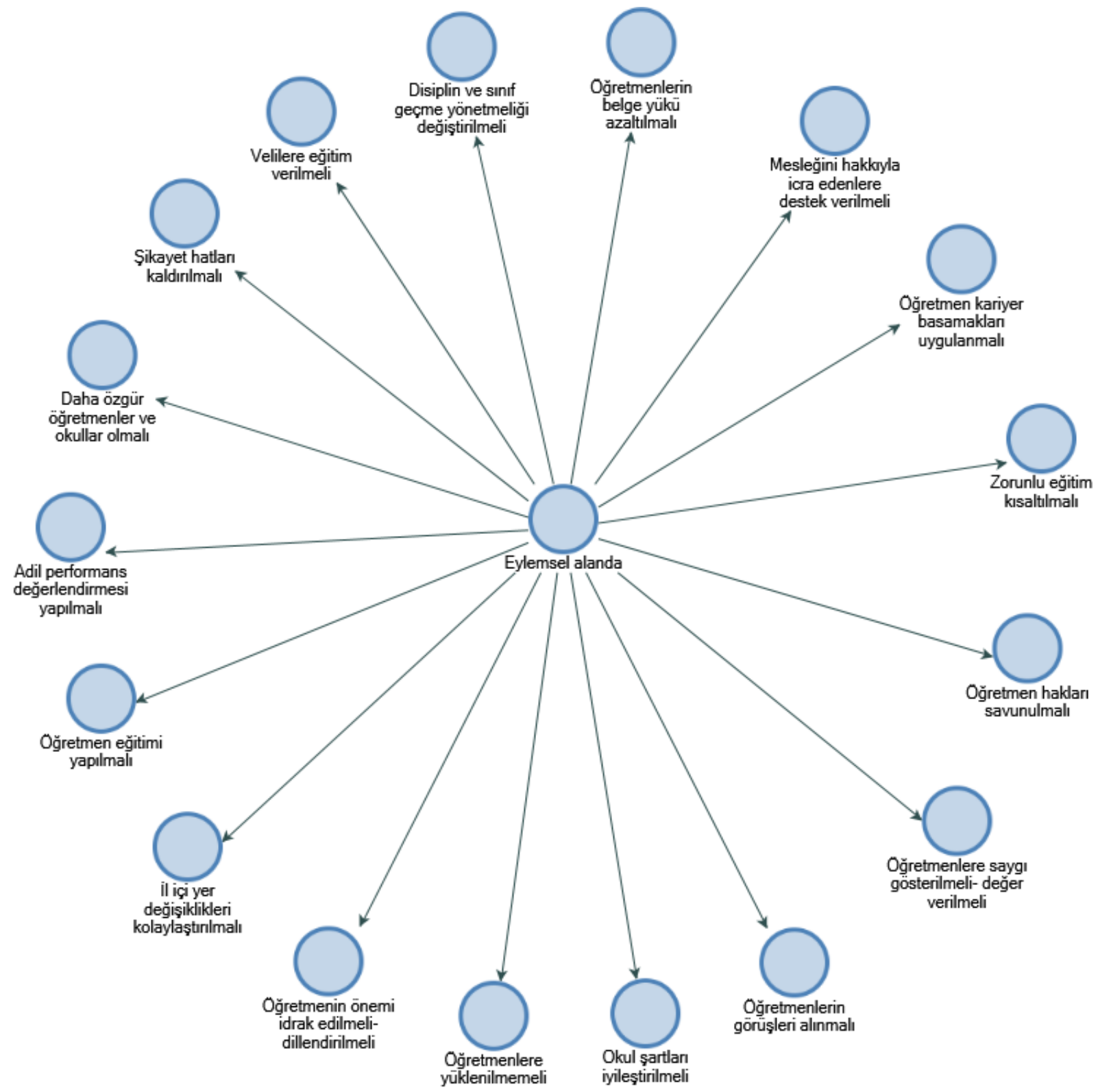

Şekil 6. Mesleki imaja katkıda bulunmak üzere MEB ve siyasilerin eylemsel alanda yapması gerekenler

Mesleki imaja katkıda bulunmak üzere MEB ve siyasilerin eylemsel alanda yapması gerekenler alt temasına ilişkin öğretmen görüşleri; öğretmenlerin belge yükü azaltılmalı $(n=2)$, mesleğini hakkıyla icra edenlere destek verilmeli $(n=1)$, öğretmen kariyer basamakları uygulanmalı $(n=2)$, zorunlu eğitim kısaltılmalı $(n=1)$, öğretmen hakları savunulmalı $(n=1)$, öğretmenlere saygı gösterilmeli-değer verilmeli $(n=8)$, öğretmenlerin görüşleri alınmalı $(n=2)$, okul şartları iyileştirilmeli $(n=5)$, öğretmenlere yüklenilmemeli $(n=2)$, öğretmenin önemi idrak edilmeli-dillendirilmeli $(n=4)$, il içi yer değişiklikleri kolaylaştırılmalı $(n=1)$, öğretmen eğitimi yapılmalı $(n=3)$, adil performans değerlendirmesi yapılmalı $(n=1)$, daha özgür öğretmenler ve okullar olmalı $(n=1)$, şikayet hatları kaldırılmalı $(n=1)$, velilere eğitim verilmeli $(n=1)$ ve disiplin ve sınıf geçme yönetmeliği değiştirilmeli $(n=2)$ ifadeleri şeklindedir. Öğretmen görüşleri arasında en fazla ifade edilen görüşler ise öğretmenlere saygı gösterilmeli-değer verilmeli $(n=8)$ ve okul şartları iyileştirilmeli $(n=5)$ ifadeleridir. Mesleki imaja katkıda bulunmak üzere MEB ve siyasilerin eylemsel alanda yapması gerekenler alt temasına ilişkin bazı öğretmenlerin görüşleri şu şekildedir: 
K10: "Okulların şartları daha da iyileştirilmeli" (Erkek, İlkokul, Mesleki Kıdem: 6-10 yıl, Yaş: 36-40 yaş).

K13: "Öğretmenlerin de fikirlerinin alınarak gerekli düzenlemelerin yapılması gerek, ögretmene olan saygl ve kaybettiği itibar geri getirilmelidir. Bu da şikayet hattının kaldırılması, öğretmenlerin elinin güçlendirilmesiyle yapılabilir" (Erkek, Lise, Mesleki Kıdem: 26 yıl+, Yaş: 46-50 yaş).

K15: "Öğretmenliğin kutsal ve bir o kadar da zor bir meslek olduğu siyasiler ve toplumun ileri gelenleri tarafindan dile getirilmeli. Çünkü ögretmenlik denince şubat tatili ve yaz tatilinin olduğu, hatta yarım gün çalışıldı̆̆l gibi düşünceler dillendirilirken; öğretmenin birçok öğrenciyle aynı anda ilgilenmesinin ve onlara bir şeyler öğretmek için ne kadar performans sarf ettiğine çok az değinilir" (Erkek, Lise, Mesleki Kıdem: 26 yı1+, Yaş: 50 yaş + ).

K19: "Sinıf geçme yönetmeliği değiştirilmeli. Disiplin artırılmal, yaptırımlar sağlanmalı." (Erkek, Ortaokul, Mesleki Kıdem: 6-10 yıl, Yaş: 31-35 yaş).

K31: "Karar alıcı konumlara öğretmenlik mesleğini icra eden kişilerin getirilmesi, personelinin haklarını savunmaları gerek. Aynı zamanda sistemin getirmiş olduğu hataları ögretmenlere mal etmemeleri gerekir" (Erkek, Ortaokul, Mesleki Kıdem: 1-5 yıl, Yaş: 26-30 yaş).

Mesleki imaja katkıda bulunmak üzere MEB ve siyasilerin ekonomik ve sosyal alanda yapması gerekenler Şekil 7'de sunulmuştur.

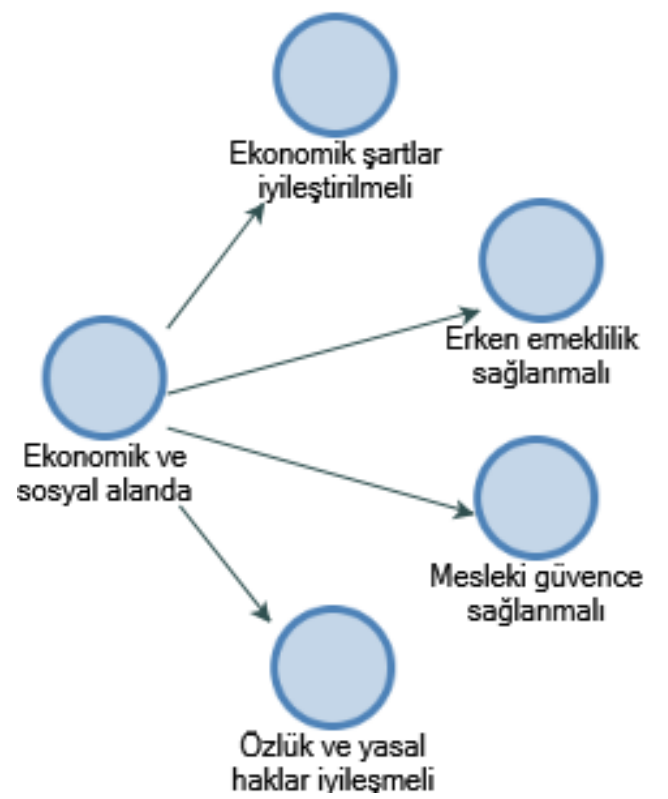

Şekil 7. Mesleki imaja katkıda bulunmak üzere MEB ve siyasilerin ekonomik ve sosyal alanda yapması gerekenler

Mesleki imaja katkıda bulunmak üzere MEB ve siyasilerin ekonomik ve sosyal alanda yapmas1 gerekenler alt temasına ilişkin öğretmen görüşleri; ekonomik şartlar iyileştirilmeli $(n=10)$, erken emeklilik sağlanmalı $(\mathrm{n}=1)$, mesleki güvence sağlanmalı $(\mathrm{n}=1)$ ve özlük ve yasal haklar iyileştirilmeli $(\mathrm{n}=5)$ ifadeleri olarak ortaya çıkmıştır. Öğretmen görüşleri arasında en fazla ifade edilen görüşler ise ekonomik şartlar iyileştirilmeli $(n=10)$ ve özlük ve yasal haklar iyileştirilmeli $(n=5)$ ifadeleridir. Mesleki imaja katkıda bulunmak üzere MEB ve siyasilerin ekonomik ve sosyal alanda yapması gerekenler alt temasına ilişkin bazı öğretmenlerin görüşleri şu şekildedir:

K9: "Bakanlı̆̆ımızın özlük haklarımızı iyileştirmesi gerekli” (Erkek, İlkokul, Mesleki Kıdem: 1620 y1l, Yaş: $36-40$ yaş).

K27: "Maaş artışı yapılmalıdır. Çünkü ne yazık ki toplumumuzda ne kadar çok paranız varsa o kadar değer görüyorsunuz” (Kadın, Ortaokul, Mesleki Kıdem: 6-10 yı1, Yaş: 26-30 yaş).

K36: "Öğretmeni sorunlardan sorumlu değil sorunların çözümü için muhtaç olunan merci olarak görerek haklarının ve imkanlarının artırlması gerek." (Kadın, İlkokul, Mesleki Kıdem: 1-5 yıl, Yaş: 26-30 yaş).

Mesleki imaja katkıda bulunmak üzere MEB ve siyasilerin politik alanda yapması gerekenler Şekil 8'de sunulmuştur. 


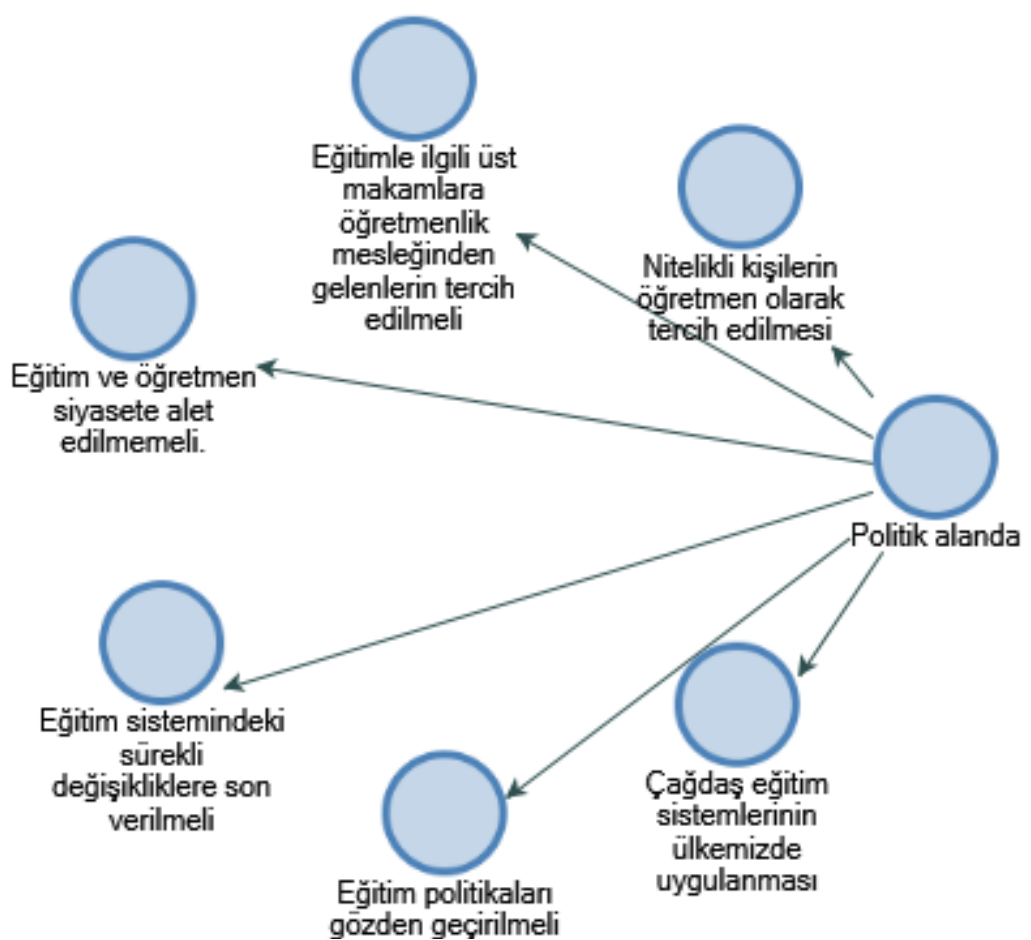

Şekil 8. Mesleki imaja katkıda bulunmak üzere MEB ve siyasilerin politik alanda yapması gerekenler

Mesleki imaja katkıda bulunmak üzere MEB ve siyasilerin politik alanda yapması gerekenler alt temasına ilişkin öğretmen görüşleri; nitelikli kişiler öğretmen olarak tercih edilmeli $(n=4)$, eğitimle ilgili üst makamlara öğretmenlik mesleğinden gelenler tercih edilmeli $(n=2)$, eğitim ve öğretmen siyasete alet edilmemeli $(n=6)$, eğitim sistemindeki sürekli değişikliklere son verilmeli $(n=4)$, eğitim politikaları gözden geçirilmeli $(n=1)$ ve çağdaş eğitim sistemleri ülkemizde uygulanmalı $(n=1)$ ifadeleri şeklindedir. Öğretmen görüşleri arasında en fazla ifade edilen görüş ise eğitim ve öğretmen siyasete alet edilmemeli $(n=6)$ ifadesidir. Mesleki imaja katkıda bulunmak üzere MEB ve siyasilerin politik alanda yapması gerekenler alt temasına ilişkin bazı öğretmenlerin görüşleri şu şekildedir:

K8: "Saymakla bitmez desem... Öncelikle bir ülkede geleceğin en büyük dayană̆ı olan eğitimdeki sürekli değişikliklere son verilmeli. Kalıcı köklü sistemler üzerine devam edilmeli. Son yıllarda ögretmenlerin kaybolan otoritesi ve saygınlığı geri kazandırılmalı" (Kadın, İlkokul, Mesleki Kıdem: 11-15 y1l, Yaş: 31-35 yaş).

K16: "Mevcut negatif durumun en büyük sorumlusu olarak neredeyse tüm eğitim politikaları gözden geçirilmeli, her türlü siyasi, ideolojik etkilerden arındırılmalı, öğretmen imajını düzeltecek adımlar atılmall, somut ve profesyonel (bilimsel) kararlar alınmalı" (Erkek, Ortaokul, Mesleki Kidem: 11-15 y1l, Yaş: 31-35 yaş).

K20: "MEB'in siyasetten kurtulması gerekir. Siyasi olarak değil de çağa uygun bir sistem ve ihtiyaçlara göre geliş̧tirilen sistem olması gerekir" (Erkek, Ortaokul, Mesleki Kıdem: 6-10 yıl, Yaş: 31-35 yaş).

K24: "Eğitim sistemiyle oynamaktan vazgeçilmeli, öğretmenlik mesleğini yapanlardan müsteşar, bakan seçilmeli" (Kadın, Lise, Mesleki Kıdem: 11-15 yıl, Yaş: 36-40 yaş).

K32: "Eğitimde ileri gitmiş ülkelerin eğitim istemlerini bütünüyle ele alarak, bizim ülkemizde uygulanacak hale getirilmesi veya bunlardan faydalanarak yerli ve milli kalıcı bir eğitim sistemi getirilmeli" (Erkek, Ortaokul, Mesleki Kıdem: 1-5 yıl, Yaş: 26-30 yaş).

K40: "Öğretmenlik imajının iyileştirilmesi için ayrıca ögretmen seçme ve atama işleminde titiz davranılmall, öğretmenliği her anlamda yapacak kalifiye kişiler öğretmen olarak tercih edilmelidir" (Erkek, İlkokul, Mesleki Kıdem: 11-15 yıl, Yaş: 36-40 yaş). 


\section{TARTIŞMA ve SONUÇ}

Elazığ ilindeki ilkokul, ortaokul ve liselerde görev yapan öğretmenlerin "öğretmenlik mesleğinin imajı" hakkındaki görüşlerini belirlemeyi amaçlayan araştırma sonucunda aşağıdaki sonuçlara ulaşılmıştır:

Araştırmada öğretmenlerin çoğunluğunun mesleki imajları hakkında olumsuz, az sayıda öğretmenin ise mesleki imajları hakkında olumlu görüşe sahip oldukları belirlenmiştir. Mesleki imajları hakkında olumlu görüş belirten öğretmenler bunu; öğretmenliğin her dönem saygın bir meslek olarak görülmesi, öğretmenlerin gelecek nesilleri yetiştirmelerindeki rolü ve onların topluma örnek olmaları gibi unsurlarla ifade etmişlerdir. Mesleki imajları hakkında olumsuz görüş belirten öğretmenler ise; mesleki imajın öğretmenlerin hal ve hareketlerinden, toplumun bakış açısından ve siyasilerin yaklaşımından olumsuz yönde etkilendiğini belirtmişlerdir. Öğretmenlerin mesleki imajlarını olumsuz olarak algılamalarında; öğretmen eğitiminin yetersizliği, öğretmenlerin iletişim, giyim-kuşam ve davranış noktalarındaki eksiklikleri, velilerin ve öğrencilerin öğretmenlere olan olumsuz yaklaşımları, mevcut öğretmen şikâyet hatları, öğretmenlere değer verilmemesi, onlara danışılmaması, öğretmenlerin öğrenciler üzerinde etkilerinin olmaması, düşük maaş alındığı düşüncesi ve öğretmenliğin kolay ve tatillerle anılan bir meslek olarak algılanması gibi unsurlar öne çıkmaktadır. Öğretmenlerin mesleki imajları hakkında yüksek oranda olumsuz görüşe sahip olmalarında, onların toplumsal konumları ile sosyal ve ekonomik şartlarının yeterli düzeyde olmadığ 1 yönündeki algılamaları sebep olabilir. Gökırmak'ın (2006) "öğretmen statüleri üzerine bir araştırma" adlı çalışması ve Aydın, Canavar ve Akkın'ın (2018) "öğretmenlerin, öğretmenlik mesleği ve ögretmenliğin toplumsal statüsüne ilişkin görüşlerinin belirlenmesi” adlı çalışmalarında, öğretmenlik mesleğinin toplumsal statüsünün düşük olduğu belirlenmiştir. Torun'un (2010) "farklı statülerde çalışan öğretmenlerin öğretmenlik mesleğine bakışları (Isparta örneği)" adlı çalışmasında da öğretmenlerin yarıdan fazlasının öğretmenlik mesleğine gereken değerin verilmediğini düşündüğü belirlenmiştir. Aynı şekilde Karaman, Acar, Kılıç, Buluş ve Erdoğan'ın (2013) "Sakarya ilinde görev yapan öğretmenlerin gözüyle öğretmenlik mesleğinin statüsü ve saygınlığı" adlı çalışmalarında öğretmenlerin mesleklerinin yeterince saygın görülmediği görüşüne sahip oldukları belirlenmiştir. TEDMEM'in (2014) Ankara'nın 22 farklı ilçesindeki 105 okulda görev yapan 1701 öğretmenin mesleklerini algılama biçimleri, meslekleriyle ilgili doyum düzeyleri ve mesleki bağlılık düzeylerini saptamak amacını taşıyan çalışmada öğretmenler bireysel olarak mesleklerini gurur duyulacak, saygın, keyif verici, ideal meslek olarak nitelerken, öğretmenliğin aynı zamanda toplum için en önemli meslekler arasında yer aldığını ve öğretmenlerin topluma yön veren bireyler olduğunu düşünmektedirler. Buna karş1lık öğretmenlerin toplumun öğretmenlik mesleğini algılayışlarına ilişkin görüşleri genel olarak öğretmenlik mesleğinin saygınlığının ve imajının düzelmeyecek kadar yıprandığı, toplumun öğretmenlerin sorunlarına karşı duyarlı davranmadı̆̆1 şeklindedir. Bununla birlikte öğretmenler, çocuklarla uğraşmanın başkalarınca önemli gibi sunulan, ancak çok ciddiye alınmayan bir iş olduğunu düşünmektedirler. Sözer'in (2015) çalışmasında da Mersin kırsalındaki köy ilkokul ve ortokullarında görev yapan öğretmenlerin yüzde 70 civarındaki kısmının öğretmenlik mesleğinin toplum içerisinde değersizleştiğini, saygınlığını yitirdiğini, hak ettiği değeri görmediğini, değerinin içselleştirilmediğini ve ekonomik statüsünün düşük olduğunu ifade ettikleri görülmektedir. Bu çalışmada öğretmenlik mesleğinin, toplum içerisinde saygın, önemli, kutsal ve güvenilir bir meslek olduğunu ifade eden öğretmenlerin oranı ise oldukça düşüktür. Benzer şekilde Ünsal ve Bağçeci'nin (2016) kamu ve özel okullarda görev yapan öğretmenlerin mesleki imajlarına ilişkin görüşlerini belirlemek ve mesleki imaja etki eden faktörlerin neler olduğunu tespit etme amacını taşıyan çalışmalarında da öğretmenler öğretmenlik mesleğinin imajını genel olarak olumsuz bulmuşlardır. Olumlu görüş belirten katılımcılar nedenlerini; mesleğin kutsallı̆̆ının devam etmesi, 90'l1 yıllardan itibaren öğretmenlerin ekonomik koşullarının iyileşmesi, diğer memurlara göre mesleğin konumunun daha iyi durumda olması şeklinde belirtmiştir. Olumsuz görüş belirten katılımcılar ise öğretmenlik mesleğinin toplum tarafından önemli bir meslek olarak görülmemesi, mesleğin profesyonel bir meslek olarak algılanmaması, genel olarak memurlara yönelik negatif algının öğretmenler için de oluşmaya başlaması şeklinde görüş belirtmiştir. Yine Ulutaş'ın (2017) öğretmenlerin bakış açısından Türkiye'de öğretmenlik mesleğinin mevcut toplumsal statüsü ile bu statüye etki eden olumlu ve olumsuz faktörleri belirleme amacını taşıyan çalışmasında öğretmenlerin büyük bir çoğunluğunun (\%87) öğretmenlik mesleğinin statüsünü düşük bulduğu, sadece \%13'ünün mesleklerinin statüsü hakkında olumlu görüş bildirdiği belirlenmiştir. Benzer şekilde Mutluer'in (2018) çalışmasında, öğretmenlerin çoğunluğunun öğretmenlik mesleğinin sosyal statüsünün düşük düzeyde, az sayıda öğretmenin ise öğretmenlik mesleğinin sosyal statüsünün orta düzeyde olduğu görüşüne sahip oldukları belirlenmiştir. Aynı zamanda hiçbir öğretmenin mesleklerini yüksek statülü olarak tanımlamadığı görülmüştür. Öğretmenlerin toplumun öğretmenlik mesleğini algılayışlarına ilişkin görüşlerini belirlemeyi amaçlayan bir diğer araştırma da OECD (2014) tarafından yapılan TALIS 2013 [Teaching and Learning International Survey] uluslararası araştırmasıdır. 
Bu araştırmanın verilerine göre araştırma yapılan ülkelerdeki tüm öğretmenlerin ortalama olarak 1/3’ünden daha azı öğretmenliğin toplumda değerli bir meslek olduğuna inanmaktadır. Bu araştırmada özellikle Hırvatistan, Fransa, Slovak Cumhuriyeti, İspanya ve İsveç’teki öğretmenlerin \%10'undan daha azının öğretmenliğin toplumda değerli bir meslek olduğuna inandığı; buna karşıllk Malezya, Singapur, Kore ve Birleşik Arap Emirlikleri'nde ise öğretmenlerin 2/3'ünden fazlasının öğretmenliğin toplumda değerli bir meslek olduğu görüşüne sahip olduğu belirlenmiştir. Bu çalışmaların bulgularıyla mevcut çalışmanın bulguları benzerlik göstermektedir. Buna karşılık; Ceviz'in (2018) öğretmenlerin bakış açısıyla, toplumda öğretmenlik mesleğinin nasıl görüldüğü ve bu algının öğretmenlerin mesleki motivasyonuyla olan ilişkisinin belirlenmesinin amaçlandığı araştırmasında öğretmenlerin, toplumun öğretmenlik mesleğini nasıl gördüğüne ilişkin algılarının "orta" düzeyde olduğu belirlenmiş̧tir. Yine Doğan'ın (2018) çalışmasında da öğretmenlerin, mesleğin imajı hakkındaki görüşlerinin "orta düzeyde" olduğu belirlenmiştir. Yurdakal'ın (2019) "öğretmen adaylarının öğretmenlik mesleğini seçmelerinde rol alan etmenler” adlı çalışmasında öğretmen adaylarının öğretmenlik mesleğini seçmelerinde mesleğin saygınlığı, ekonomik statüsü, atanma oranının yüksekliği ve iş tanımının net olması gibi unsurların etkili olduğu belirlenmiş̧tir. Yurdakul, Gür, Çelik ve Kurt'un (2016) Türkiye geneli kamuda temel eğitim ve ortaöğretim kurumlarında görev yapan öğretmenlerin kendi mesleklerini ve mesleki statülerini nasıl algıladığını öğretmen görüşlerine başvurarak kapsamlı bir şekilde ortaya koyma amaçlı çalışmalarında ise öğretmenlerin \%61,4'ü öğretmenliğin en saygın mesleklerden biri olarak tanımlamakta ve öğretmenlerin \%61,9'u da öğretmenliğin toplumda saygın bir kişi olma imkânını kendisine vermesi bakımından memnun olduğunu ifade etmişlerdir. Benzer şekilde Everton, Turner, Hargreaves ve Pell'in (2007), İngiltere'deki öğretmenlik mesleğine ilişkin kamu algılarını belirlemek üzere yaptıkları çalışmalarında halkın \%50'sinin öğretmenliğin çekici bir kariyer olduğuna inandığ 1 belirlenmiştir. Bu çalışmaların bulgularıyla mevcut çalışmanın bulguları ise farklılık göstermektedir.

Araştırmada öğretmenlerin çoğunluğu mesleki imajlarının geçmişe oranla daha kötü durumda olduğunu, az sayıda öğretmen ise mesleki imajlarının geçmişe oranla aynı durumda olduğu belirtmişlerdir. Mesleki imajlarının geçmişe oranla daha kötü durumda olduğu belirten öğretmenler, bunu toplumun bakış1, ögrretmen seçme ve atamasında yapılan yanlışlıklar, mesleki yetersizlik, geçmişe oranla öğretmen adaylarının atanmasında yaşanan güçlükler, öğretmenliğin kolay bir meslek olarak algılanması, ögretmenliğin sadece bir zanaat ya da bir iş olarak görülmesi, bilgiye ulaşmanın getirdiği kolaylıkla birlikte öğretmenin öneminin azalması, öğretmene geçmişe oranla daha az saygı gösterilip daha az değer verilmesi, düşüncelerinin önemsenmemesi ve öğretmenlerin geçmişe oranla daha az fedakârlık yapmalarıyla ifade etmişlerdir. Öğretmenlerin mesleki imajlarının geçmişteki mesleki imajlarına göre daha kötü durumda olduğu görüşünü yüksek oranda ifade etmelerinde, ekonomik ve toplumsal değişimlerin öğretmenlik mesleğine yüklenen anlamı olumsuz olarak etkilediği yönündeki algılamaları sebep olabilir. TEDMEM'in (2014) araştırmasında öğretmenlerin toplumun öğretmenlik mesleğini algılayışlarına ilişkin görüşleri genel olarak öğretmenlik mesleğinin saygınlığının ve imajının düzelmeyecek kadar yıprandığı şeklindedir. Benzer şekilde Ünsal ve Bağçeci'nin (2016) çalışmalarında da öğretmenler, mesleki imajlarının genel olarak geçmişe oranla daha kötü durumda olduğu görüşünü belirtmişlerdir. Yine Doğan'in (2018) çalışmasında, öğretmenlerin mesleğe ve öğretmenlere geçmişte daha çok saygi gösterilirken, günümüzde bunun azaldığını da ifade ettikleri belirlenmiştir. Gökırmak'ın (2006) ve Aydın vd.'nin (2018) çalışmalarında da öğretmenlik mesleğinin toplumsal statüsünün son yıllarda giderek azaldığı belirlenmiştir. Yurdakul, Gür, Çelik ve Kurt'un (2016) çalışmalarında ise, öğretmenlerin üçte ikiden fazlası, $(\% 65,7)$ öğretmenlerin toplumsal statülerinin gün geçtikçe düştügünü ve \%38,9'u da öğretmenlik mesleğinin itibarının ve imajının düzelmeyecek kadar yıprandığını ifade etmişlerdir. Yine Akcan ve Polat'ın (2016) "Eğitim Konulu Türk Filmlerinde Öğretmen İmajı: Öğretmen İmajına Tarihi Bakış" adlı çalışmalarında eğitim konulu Türk filmlerinde öğretmenlerin Cumhuriyetin ilk y1llarında Osmanlı kültürünün etkisinde olan kıyafet içerisinde oldukları ve akıcı ve süslü bir Türkçeyle konuştukları; sonraki yıllarda ise modern kıyafetler içerisinde olmalarına rağmen konuşmalarında gerileme yaşandığı, onların büyüdükleri yörenin özelliklerini taşıyan bir Türkçe ile konuştukları belirlenmiştir. Aynı zamanda ilk yıllarda kendini tamamen adamış öğretmen imajı, sonraki yıllarda yerini ekonomik anlamda sıkıntı çeken öğretmen imajına bırakmıştır. Yine ilk dönemlerdeki filmlerde öğretmenlerin din-modernite mücadelesi içinde, sonraki dönemde ekonomik mücadele içinde, en sonda ise kültürel farkl1lıklarla mücadele içinde olduğu görülmektedir. Hargreaves vd.'nin (2007), 1967-2006 yılları arasındaki İngiltere'deki öğretmenlerin statüsündeki değişimleri inceledikleri çalışmalarında, 1967'den 2003 y1lına kadar öğretmen statüsünde sürekli bir düşüş tespit edilmiş, 2006 yılında ise öğretmenlerin statüleri hakkındaki algılamalarında 2003 
yılına göre küçük önemsiz bir atış olduğu belirlenmiştir. Bu çalışmaların bulgularıyla mevcut çalışmanın bulgularının benzerlik göstermektedir.

Mesleki imajlarına katkıda bulunmak üzere öğretmenlerin yapması gerekenlerde; en fazla kendini geliştirme-yenileme ifadesi ön plana çıkmıştır. Mesleki imajlarına katkıda bulunmak üzere öğretmenlerin diğer yapması gerekenler ise; örnek davranışlar sergileme, konuşma, davranış ve giyimine özen gösterme, mesleki bilinç ve sorumluluğa sahip olma, fedakarlık ve çözüm odaklı olma olarak ifade edilmiştir. Öğretmenlerin mesleki imajlarına katkıda bulunmak üzere özellikle kendilerini geliştirme ve yenileme hususunu belirtmeleri, onların toplumsal talepleri karşılama noktasındaki yeterliliklerine vurgu yapmaktadır. Bu görüşün yüksek oranda ifade edilmesinde toplumsal talepleri karşılamanın mesleki imaja katkısının olabileceği düşüncesi etkili olabilir. Karaman vd.'nin (2013) çalışmalarında öğretmenlerin çağın eğitim anlayışına uygun olarak kendilerini geliştirememelerinin mesleğin statüsü ve saygınlığına olumsuz etki ettiği görüşüne sahip oldukları saptanmıştır. Semerci, Semerci, Eliüşük, ve Kartal'ın (2012) "öğretmenlik mesleğinin gündemine ilişkin öğretmen görüşleri (Bartın ili örneği)" adlı çalışmalarında ise öğretmenlerin yarısından fazlasının (\%52.7) öğretmenlerin okumadığı görüşünde olduğu belirlenmiştir. Öğretmenlik Mesleği Genel Yeterlikleri'nde (MEB, 2017b), “Tutum ve Değerler” yeterlik alanındaki öğretmenlerin yeterlik göstergelerinden biri de kişisel ve mesleki yönden kendini geliştirmeye yönelik faaliyetlerde bulunur ifadesidir. Aynı zamanda öğretmenlerin gelişimleri için 15. Milli Eğitim Şûrası'nda öğretmenler yüksek lisans ve doktoraya yönlendirilmeli (MEB, 1996) şeklinde tavsiye kararı bulunmaktadır. Ünsal ve Bağçeci'nin (2016) çalışmalarında da mesleki imajın geliştirilmesi için öğretmenlerin yapması gerekenlere ilişkin katılımcı görüşleri; derslerinde yeterli olmalı, kendilerini geliştirmeli, birlik ve beraberlik içinde davranmalı, kendilerine ve mesleklerine saygı duymalı alt temaları şeklindedir. Öğretmenlerin görüşleri arasında en fazla frekansa sahip olan alt tema ise öğretmenlerin kendilerini yenilemeleri, geliştirmeleri alt temalarıdır. Bu çalışmanın bulgularıyla mevcut çalışmanın bulgularının benzerlik gösterdiği söylenebilir.

Mesleki imaja katkıda bulunmak üzere MEB ve siyasilerin yapması gerekenlerde; en fazla ekonomik şartlar iyileştirilmeli ve öğretmenlere saygı gösterilmeli-değer verilmeli ifadeleri ortaya çıkmıştır. Mesleki imaja katkıda bulunmak üzere MEB ve siyasilerin diğer yapması gerekenler ise eğitim ve öğretmen siyasete alet edilmemeli, özlük ve yasal haklar iyileştirilmeli ve okul şartları iyileştirilmeli olarak ifade edilmiştir. Öğretmenlerin mesleki imajlarına katkıda bulunmak üzere özellikle ekonomik şartlarının iyileştirilmesi görüşünü yüksek oranda ifade etmelerinde onların iyi ekonomik şartların iyi bir imaj sağlayacağı yönündeki algılamaları sebep olabilir. Yine mesleki imajlarına katkıda bulunmak üzere öğretmenlere saygı gösterilmesi ve değer verilmesi görüşünün öğretmenler tarafından yüksek oranda ifade edilmesi onların değer verilen, saygı duyulan mesleklerin imajlarının da iyi olacağı yönündeki algılamalarından kaynaklanabilir. Semerci vd. (2012) çalışmalarında öğretmenlerin sadece \% 8'inin mevcut maaşlarını yeterli gördüğü, büyük çoğunluğu oluşturan \% 67.5'lik kesimin maaşlarının iki katına çıkarılması gerektiği görüşüne sahip olduğu belirlenmiştir. Gökırmak'ın (2006) ve Aydın vd.'nin (2018) çalışmalarında da öğretmenlik mesleğinin statüsünün yükseltilmesi ile İlgili önerilerde en yüksek ortalamayla "tamamen katılıyorum" düzeyinde ifade edilen maddenin "öğretmenlerin maaş ve ücretleri günün koşullarına göre düzenlenmelidir" maddesi olduğu belirlenmiştir. Uygun'un (2012) "basında öğretmen sorunları" adlı çalışmasında gazetelerde öğretmenlerin sırasıyla en çok ekonomik, özlük, örgütlenme türünden mesleki sorunları yer almıştır. Öğretmenlerin meslek dışı sorunlarında ise siyasal sorunlar gazetelere yansıyan sorunlar olarak yer almıştır. Siyasi sorunlarda daha çok siyasilerin öğretmenlere hak ettikleri değeri vermemesi ve öğretmen ile öğretmen örgütlerinin siyasileri hedef alan demeçleri bulunmaktadır. Çüm ve Doğan'ın (2016) "öğretmenlerin çalışma yaşamında güdülenme düzeylerini artıran faktörlerin önem sırasının belirlenmesi" adlı çalışmalarında öğretmenlerin çalışma yaşamında güdüleme düzeyini en fazla artıracak faktörün "öğretmenlik mesleğinin saygınlığını artırmaya yönelik çalışmaların yapılması", ikinci faktörün ise "maaş ve ücretlerin artırılması" olduğu belirlenmiştir. Esen, Temel ve Demir'in (2017) "Türkiye'deki öğretmenlerin karşılaştıkları mesleki sorunların ikili karşılaştırma yöntemi ile ölçeklenmesi" adlı çalışmalarında öğretmenlerin en önemli ilk üç sorun alanının sırasıyla M.E.B. eğitim politikaları, mesleki saygınlığın azalması ve fiziki koşullar ve alt yapı yetersizliği olduğu belirlenmiştir. 15. Milli Eğitim Şûrası'nda alınan tavsiye kararlarından biri "öğretmenlik mesleği ekonomik ve sosyal yönden iyileştirilmelidir" şeklindedir (MEB, 1996). Yine 16. Milli Eğitim Şûrası'nda "Mesleki ve Teknik Eğitim Alanına Öğretmen ve Yönetici Yetiştirme" başlığı altında; öğretmenlere görev, yetki ve sorumluluklarına uygun sosyal ve ekonomik bir statüsü kazandırılmalı ve öğretmenlerin çalışma koşulları iyileştirilmeli, onların emeklilik sonrası yaşam standartlarını yükseltecek yasal düzenlemeler yapılmalıdır (MEB, 1999) şeklinde tavsiye kararları alınmıştır. 2017-2023 Öğretmen Strateji Belgesi'nde (MEB, 2017a) ise, 
öğretmenlik mesleğine yönelik algıy iyileştirmek ve mesleğin statüsünü güçlendirmek amacıyla; öğretmenlik mesleğinin statüsünü güçlendirmek, öğretmenlik çalışma şartlarını iyileştirmek, kurumlar ve bölgeler arası farkl1lıklara göre iyileştirici tedbirler almak ve kariyer ve ödül sistemini geliştirmek hedefleri yer almaktadır. Hargreaves vd.'nin (2006) çalışmalarında da öğretmenliğin çalışma koşulları ve finansal olmayan faydalarının iyileştirilebilmesi, dış kontrol ve düzenlemenin gevşetilmesi ve öğretmenliğin saygın ve değerli bir otorite olarak görülmesinin öğretmenlik mesleği ve yüksek statülü mesleğin algıları arasındaki farkın kapanmasında önemli unsurlar olduğu sonucuna ulaşılmıştır. Ünsal ve Bağçeci'nin (2016) çalışmalarında öğretmenlerin mesleki imajı geliştirmek için MEB, siyaset ve diğer aktörlerin yapması gerekenlere ilişkin görüşleri; medyanın sorumlu yayını, özlük haklarının ve ekonomik koşulların iyileştirilmesi, bakanlığın ve siyasetin yapması gerekenler, sendikaların yapması gerekenler, eğitim anlayışının revize edilmesi, öğretmen katılımı, öğretmen yetiştirme, daha etkin kurs ve seminer programının yapılması şeklinde sekiz alt tema altında toplanmıştır. Bakanlığın ve siyasetin yapması gerekenler alt teması en fazla frekansa sahip alt temadır. Ünsal'ın (2018) öğretmenlik mesleğinin statüsünün düşük olmasının nedenlerini ve öğretmenlik mesleğinin statüsünü artırmaya yönelik çözüm önerilerinin neler olduğunu uzman ve öğretmen görüşleri bağlamında belirlemeyi amaçladığı çalışmasında öğretmenlik mesleğinin statüsünün düşük olmasının nedenleri sırasıyla; öğretmen yetiştiren kurumlar, çalışma koşulları, ekonomik koşullar, medya, toplum, öğretmen niteliği, yöneticiler ve eğitim politikaları olduğu sonucuna ulaşılmıştır. Bu nedenler içerisinde katılımcılar tarafından en sık ifade edilen alt neden öğretmenlerin maaşının düşük olması ve mesleğin değerinin toplum tarafından anlaşılamamasıdır. Bu çalışmaların bulgularıyla mevcut çalışmanın bulgularının benzerlik gösterdiği söylenebilir. Öğretmenlerin mesleki imajlarına katkı bulunmak üzere MEB ve siyasilerin yapması gerekenlerde ifade ettikleri görüşlerden biri de özlük ve yasal hakların iyileştirilmesi ifadesidir. Öğretmenlerin özlük ve yasal haklarını etkileyen unsurlardan biri onların; kadrolu, sözleşmeli, ücretli, vekil öğretmen gibi farklı statülerde istihdam edilmeleridir. Yapılan araştırmalar öğretmenlerin farklı statülerde istihdam edilmelerinin öğretmenliğin toplumsal değerini etkilediği yönündedir. Örneğin; Bayram'ın (2009) “öğretmenlerin istihdam biçimi farklılıkları ve yarattığı sorunlar: Ankara'da çalışan sözleşmeli ve ücretli öğretmenlerin görüşlerine dayalı bir araştırma" adlı çalışmasında özellikle ücretli öğretmenlerin kendilerini toplum tarafından ikinci sınıf öğretmen statüsünde görüldükleri görüşüne sahip oldukları belirlenmiştir. Yine ücretli ve sözleşmeli öğretmenlerin, çoğunlukla özlük hakları ile ilgili mevcut uygulamayı kendileri açısından yetersiz gördüğü, bazı haklarının da uygulamada kısıtlandığını düşündüğü belirlenmiştir. Torun'un (2010) çalışmasında ise öğretmenlerin yaklaşık olarak yarıdan fazlasının öğretmenlerin farklı statülere ayrılmasını toplumsal değerini düşürdüğüne inandığı belirlenmiştir. 18. Milli Eğitim Şûrası'nda "Öğretmenin Yetiştirilmesi, İstihdamı ve Mesleki Gelişimi” başlı̆̆ı altında "öğretmenlerin gelir düzeyi ve statülerinin yükseltilmesine yönelik çalışmalara hız verilmeli; öğretmen istihdamında kadrolu, sözleşmeli, ücretli, vekil öğretmenlik gibi farklı uygulamalar kaldırılarak tüm öğretmenlerin kadrolu olarak istihdamı sağlanmalı; mevcut sözleşmeli öğretmenler kadroya geçirilmeli” (MEB, 2010) şeklinde öğretmenlerin tek bir statüde ve kadrolu olarak istihdam edilemeleri yönünde aldığı tavsiye kararı bulunmaktadır. Aynı zamanda atanamayan öğretmenlerin de toplumsal statüleri konusunda sorun yaşadıklarını söylemek mümkündür. Kiraz ve Kurul'un (2018), "Türkiye'de öğretmen işsizliği ve ataması yapılmayan öğretmenler hareketi" adlı çalışmalarında ataması yapılmayan öğretmenlerin çoğunlukla dershane öğretmenliği ve ücretli öğretmenlik başta olmak üzere lise ve daha alt düzeyde eğitim gerektiren, düşük ücretli, geçici, kesintili, güvencesiz işleri yaparken bir yandan da KPSS'ye hazırlanarak herhangi bir devlet okuluna atanarak asıl olan işlerini yapabilmenin çabası içerisine girdikleri belirlenmiştir. Öğretmenlerin atanamama sorununun öğretmen arz-talep dengesinin sağlıklı olarak kurulamaması sonucu olduğu söylenebilir. 17. Milli Eğitim Şûrası'nda “Eğitimde Nitelik" başlığı altında; “öğretmen niteliğinin artırılması için, eğitim fakültelerinin sayıları ülkenin gereksinimlerine göre sınırlandırılmalı; istihdam politikası doğrultusunda yeni eğitim fakülteleri açılmalıdır. Eğitim fakültelerinin öğrenci kontenjanlarının belirlenmesinde de ülkenin kısa ve uzun vadeli gereksinimleri ve eğitimin niteliğinin artırılması hedefleri göz önüne alınmalıdır" (MEB, 2006) şeklinde bu noktaya dikkat çeken bir tavsiye kararı alınmıştır.

Araştırmadan elde edilen bulgulara göre aşağıdaki öneriler yapılabilir:

1. Öğretmen yetiştiren fakültelere öğrenci alımında bir takım kıstaslar getirilebilir. $\mathrm{Bu}$ bağlamda öğretmen adaylarının Türkçeyi etkin ve doğru kullanabilmeleri, diğer insanlarla olan ilişkileri, empati kurabilme becerileri, öğretmenlik mesleğine karşı olan tutumları, çocuklara karşı yaklaşımları vb. unsurlar kıstas olarak alınabilir.

2. Öğretmen adaylarının mesleki anlamda daha yetkin olabilmeleri için okullarla daha fazla işbirliğine gidilerek öğretmenlik pratikleri artırılabilir, öğretmen adaylarının 
yetiştirilmesinde alanında uzman olan öğretmenlerden ve eğitim uzmanlarından yararlanılabilir.

3. Öğretmenler, öğrencilerini yetiştirme konusunda daha özverili davranabilmeli, mesleklerinin kutsal olduğu bilinciyle ve mesleki sorumlulukla hareket edebilmelidirler.

4. Öğretmenler iletişim becerilerini geliştirebilmeli, giyim-kuşam ve davranışlarına özen gösterebilmeli, örnek davranışlar sergileyebilmelidirler.

5. Öğretmenler kendilerini geliştirebilme adına, alanlarıyla ilgili yayınları takip edebilmeli, hizmet içi eğitim faaliyetleri, konferans, seminer vb. katılabilmeli, dünyadaki gelişmeleri takip ederek kendilerini teknolojik, toplumsal gelişimlere adapte edebilmeliler.

6. Öğretmenlerin ekonomik ve sosyal hakları iyileştirilebilir. Bu bağlamda öğretmen maaşı artırılabilir, erken emeklilik sağlanabilir. Aynı zamanda öğretmenlik kariyer basamaklarının etkin bir şekilde uygulanması sağlanabilir. 


\section{KAYNAKLAR}

Ada, Ş. ve Küçükali R. (2009). Türk eğitim sistemi ve okul yönetimi. Ankara: Anı Yayınc1lık.

Akbaşl1, S. (2009). Öğretmenlik mesleğinin özellikleri, eğitim sisteminde öğretmenin rolü, öğretmen yetiştirme alanında uygulamalar ve gelişmeler. K. Kıroğlu ve C. Elma (Ed.), Eğitim bilimine giriş̧ (s.275-322). Ankara: Pagem Akademi.

Akbulut, B. (2015). Ortaöğretim kurumlarında görev yapan öğretmenlerin örgütsel imaj algıları ile iş doyumu düzeyleri arasındaki iliş̧ki. Yayımlanmamış Doktora Tezi, Hacettepe Üniversitesi Eğitim Bilimleri Enstitüsü, Ankara.

Akcan, E. ve Polat, S. (2016). Eğitim konulu Türk filmlerinde öğretmen imajı: Öğretmen imajına tarihi bakış. Kuram ve Uygulamada Ĕ̈itim Yönetimi Dergisi, 22(3), 293-320.

Aslan, K., Aslan, N. ve Cansever B.A. (2012). Eğitim bilimine giriş. Ankara: Pegem Akademi.

Aydın, R., Canavar, O. ve Akkın, A. (2018). Öğretmenlerin, öğretmenlik mesleği ve öğretmenliğin toplumsal statüsüne ilişkin görüşlerinin belirlenmesi. 21. Yüzyllda Eğitim ve Toplum Eğitim Bilimleri ve Sosyal Araştırmalar Dergisi, 7(21), 965-990.

Aziz, A. (2011). Sosyal bilimlerde araştırma yöntemleri ve teknikleri. (6. Bask1). Ankara: Nobel Akademik Yayıncılık.

Bağçeci, B. Çetin, B. ve Ünsal, S. (2013). Öğretmenlerin mesleki imaj ölçeği. Gaziantep University Journal of Social Sciences, 12(1), 34-48.

Bal, H. (2016). Nitel araşttrma yöntem ve teknikleri: Uygulamall-örnekli. İstanbul: Sentez Yayınları.

Bayram, G. (2009). Öğretmenlerin istihdam biçimi farklllıkları ve yarattığ sorunlar: Ankara'da çalışan sözleşmeli ve ücretli ögretmenlerin görüşlerine dayalı bir araştırma. Yayımlanmamış Yüksek Lisans Tezi, Ankara Üniversitesi Eğitim Bilimleri Enstitüsü, Ankara.

Bektaş, F. (2010). Örgütsel imaj ve örgüt kültürü: Öğretmen adayı örnekleminde nedensel bir araştırma. Eğitim ve Insani Bilimler Dergisi, 1(2), 5-18.

Bilgin, N. (2006). Sosyal bilimlerde içerik analizi: Teknik ve örnek çalışmalar. (2. Baskı). Ankara: Siyasal Kitabevi.

Celep, C. (2004). Meslek olarak öğretmenlik. C. Celep (Ed.), Meslek olarak öğretmenlik (s.23-49, 3. Baskı). Ankara: Anı Yayincilik.

Celep, C. (2010). Meslek olarak öğretmenlik. C. Celep (Ed.), Eğitim bilimine giriş (s.45-74, 3. Baskı). Ankara: Anı Yayıncilik.

Ceviz, H. (2018). Toplumdaki öğretmenlik mesleğine ilişkin algı ile öğretmenlerin mesleki motivasyonu arasındaki ilişki. Yayımlanmamış Yüksek Lisans Tezi, Düzce Üniversitesi Sosyal Bilimler Enstitüsü, Düzce.

Creswell, J. W. (2013). Nitel araştırma yöntemleri: Beş yaklaşıma göre nitel araştırma ve araştırma deseni. (Bölümü çeviren Miraç Aydın, Mesut Bütün ve Selçuk Beşir Demir Editörlüğünde). Ankara: Siyasal Kitabevi.

Çalışkan, N. (2005). Öğretmenlerin özellikleri ve yeterlikleri. K. Keskinkılıç (Ed.), Öğretmenlik mesleğine giriş (s.327-353). Ankara: Pagem A Yayıncılık.

Çeliköz, N. (2004). Bir meslek olarak öğretmenlik ve etiği. M. Ç. Özdemir (Ed.), Öğretmenlik mesleğine giriş (s.333394, 2. Baskı). Ankara: Asil Yayın Dağıtım.

Çüm, S. ve Doğan, N. (2016). Öğretmenlerin çalışma yaşamında güdülenme düzeylerini artıran faktörlerin önem sirasının belirlenmesi. Kastamonu Ĕgitim Dergisi, 24(1), 119-132.

Demir, O. Ö. (2009). Nitel araştırma yöntemleri. K. Böke (Ed.), Sosyal bilimlerde araştırma yöntemleri. (s. 285-318). İstanbul: Alfa Yayınları.

Dinçer, M. K. (2001). Kişisel imaj. (3. Baskı). İstanbul: Alfa Basım Yayım Dağıtım.

Doğan, Ö. (2018). Öğretmenlerin görüşlerine göre ögrretmenlik mesleğinin imajl. Yayımlanmamış Doktora Tezi, Anadolu Üniversitesi Eğitim Bilimleri Enstitüsü, Eskişehir.

DPB. (2018). Kamu Personeli İstatistikleri. Erişim Tarihi: 02.03.2019, http://www.dpb.gov.tr/tr-tr/istatistikler/kamupersoneli-istatistikleri.

Erden, M. (2017). Eğitim bilimlerine giriş. (11. Baskı). Ankara: Arkadaş Yayınevi.

Ergun, M., Ergezer, B., Çevik, İ. ve Özdaş .A. (1999). Öğretmenlik mesleğine giriş. Ankara: Ocak Yayınları.

Esen, Y. D., Temel, F. ve Demir, E. (2017). Türkiye'deki öğretmenlerin karşılaştıkları mesleki sorunların ikili karşılaştırma yöntemi ile ölçeklenmesi. Eğitimde ve Psikolojide Ölçme ve Değerlendirme Dergisi, 8(1), 47-62.

Eskicumalı, A. (2004). Eğitim, öğretim ve öğretmenlik mesleği. Y. Özden (Ed.), Öğretmenlik mesleğine giriş̧ (s.1-32, 3. Baskı). Ankara: Pagem A Yayıncıllk.

Everton, T., Turner, P., Hargreaves, L. ve Pell, T. (2007). Public perceptions of the teaching profession, Research Papers in Education, 22:3, 247-265, DOI: 10.1080/02671520701497548

Geçikli, F. (2012). Kurum imajı. Erzurum: Fenomen Yayıncılık.

Göker, S. D. ve Gündüz, Y. (2017). Dünya ölçeğinde öğretmenlerin saygınlık statüsü ve özlük hakları. Milli Eğitim Dergisi, 46(213), 177-196.

Gökırmak, A. (2006). Öğretmen statüleri üzerine bir araştırma. Yayımlanmamış Yüksek Lisans Tezi, Yeditepe Üniversitesi Eğitim Bilimleri Enstitüsü, İstanbul.

Gönülaçar, Ş. (2016). Türkiye'de Ögrretmen İmajı ve İtibarı Üzerine Bir İnceleme. Erişim Tarihi: 11.03.2018, https://s3.amazonaws.com/academia.edu.documents/41461508/Turkiyede.Ogretmen.Imaji.ve.Itibari.sgonulac ar.2016.pdf. 
Güler, A., Halıcıoğlu, M. B. ve Taşğın, S. (2013). Sosyal bilimlerde nitel araştırma yöntemleri. Ankara: Seçkin Yayınc1lik.

Güven, D. (2010). Profesyonel bir meslek olarak Türkiye’de öğretmenlik. Boğaziçi Üniversitesi Ĕ̆itim Dergisi, 27(2), 13-21.

Hargreaves, L., Cunningham, M., Everton, T., Hansen, A., Hopper, B., McIntyre, D., ... ve Wilson, L. (2006). The status of teachers and the teaching profession: Views from inside and outside the profession. Interim Findings from the Teacher Status Project.

Hargreaves, L., Cunningham, M., Everton, T., Hansen, A., Hopper, B., McIntyre, D.,... ve Turner, P. (2007). The status of teachers and the teaching profession in England: Views from inside and outside the profession. The Chancellor, Masters and Scholars of the University of Cambridge.

Karaman, M., Acar, A., Kılıç, O., Buluş, U. ve Erdoğan, Ö. (2013). Sakarya ilinde görev yapan öğretmenlerin gözüyle “öğretmenlik mesleğinin statüsü ve saygınlı̆̆ı". VI. Ulusal Lisansüstü Eğitim Sempozyumu, (104-110). Sakarya: Sakarya Üniversitesi.

Kılıç, D. (2018). Ë̆itim bilimine giriş. (4. Baskı). Ankara: Nobel Akademik Yayıncılık.

Kiraz, Z. ve Kurul, N. (2018). Türkiye'de öğretmen işsizliği ve ataması yapılmayan öğretmenler hareketi. Mersin Üniversitesi Eğitim Fakültesi Dergisi, 14(1), 270-302.

Küçükahmet, L. (2003). Bir meslek olarak öğretmenlik. L. Küçükahmet (Ed.), Öğretmenlik mesleğine girişs (s.1-26, 4. Baskı). Ankara: Nobel Yayın Dağıtım.

MEB. (1973). Milli Ĕgitim Temel Kanunu. Erişim tarihi: 27.03.2018, http://mevzuat.meb.gov.tr/html/temkanun_0/temelkanun_0.html.

MEB (1996). 15. Milli Ĕgitim Şûrast (13-17 Mayıs 1996). Erişim Tarihi: 08.04.2019, https://ttkb.meb.gov.tr/meb_iys_dosyalar/2017_09/29165430_15_sura.pdf.

MEB (1999). 16. Milli Eğitim Şûrası (13-17 Kasım 1999). Erişim Tarihi: 10.01.2019, https://ttkb.meb.gov.tr/meb_iys_dosyalar/2017_09/29165513_16_sura.pdf.

MEB (2006). 17. Milli Eğitim Şûrast (13-17 Kasım 2006). Erişim Tarihi: 08.04.2019, https://ttkb.meb.gov.tr/meb_iys_dosyalar/2017_09/29165619_17_sura.pdf.

MEB (2010). 18. Milli Eğitim Şûrası (01-05 Kasım 2010). Erişim Tarihi: 10.01.2019, https://ttkb.meb.gov.tr/meb_iys_dosyalar/2017_09/29170222_18_sura.pdf.

MEB (2017a). Öğretmen Strateji Belgesi (2017-2023). Erişim Tarihi: 12.03.2019, https://oygm.meb.gov.tr/meb_iys_dosyalar/2017_07/26174415_Strateji_Belgesi_RG-Ylan-_26.07.2017.pdf.

MEB (2017b). Öğretmenlik Meslĕgi Genel Yeterlikleri. Erişim Tarihi: 12.03.2019, http://oygm.meb.gov.tr/meb iys dosyalar/2017 12/11115355 YYRETMENLYK MESLEYY GENEL YE TERLYKLERY.pdf.

MEB. (2018). Milli Ë̆itim İstatistikleri Örgün Eğitim 2017-2018, Erişim Tarihi: 02.03.2019, http://sgb.meb.gov.tr/meb iys dosyalar/2018 09/06123056 meb istatistikleri orgun egitim 2017 2018.pdf

Miles, M. B. ve Huberman, A. M. (1994). An expanded sourcebook: Qualitative data analysis. Thousand Oaks, CA: Sage.

Mutluer, Ö. (2018). Öğretmenlik mesleğinin sosyal statüsü: Bir olgubilim çalışması. Yayımlanmamış Yüksek Lisans Tezi, Uludağ Üniversitesi Eğitim Bilimleri Enstitüsü, Bursa.

OECD (2014). TALIS 2013 Results: An International Perspective on Teaching and Learning, OECD Publishing. http://dx.doi.org/10.1787/9789264196261-en

Özdemirci, A. (2012). Popüler kültür, tüketim psikolojisi ve imaj yönetimi: Türkiye (1950-1980). İstanbul: Beta Basım Yayım Dağıtım A.Ş.

Özüpek, M. N. (2005). Kurum imajı ve sosyal sorumluluk. Konya: Tablet Kitabevi.

Peltekoğlu, F. B. (2004). Halkla ilişkiler nedir? (3. Bask1). İstanbul: Beta Basım Yayım Dağıtım A.Ş.

Roberts, L. M. (2005). Changing faces: Professional image construction in diverse organizational settings. Academy of management review, 30(4), 685-711.

Semerci, Ç., Semerci, N., Eliüşük, A. ve Kartal, S. E. (2012). Öğretmenlik mesleğinin gündemine ilişkin öğretmen görüşleri (Bartın ili örneği). Bartın Üniversitesi Ĕgitim Fakültesi Dergisi, 1(1), 22-40.

Sönmez, V. (2004). Eğitimin tarihsel temelleri. V. Sönmez (Ed.), Öğretmenlik mesleğine girişs (s.25-60, 4. Baskı). Ankara: Anı Yayıncilık.

Sözer, Z. (2015). Köy ilkokul ve ortaokullarında görev yapan ögretmenlerin sosyolojik profilleri ve ögretmenlik mesleğine yönelik tutumları: Mersin örneği. Yayımlanmamış Yüksek Lisans Tezi, Mersin Üniversitesi Sosyal Bilimler Enstitüsü, Mersin.

Şişman, M. (2006). Ĕgitim bilimine giriş. (2. Baskı). Ankara: Pagem A Yayıncılık.

TEDMEM (2014). Öğretmen gözüyle ögretmenlik mesleği rapor dizisi: 3. Erişim tarihi: 27.03.2018, https://tedmem.org/download/ogretmen-gozuyle-ogretmenlik-meslegi? wpdmdl=968

TDK, Türkçe Sözlük. http://www.tdk.gov.tr. (27.03.2018)

Torun, F. (2010). Farklı statülerde çalışan öğretmenlerin öğretmenlik mesleğine bakışlarl (Isparta örneği). Yayımlanmamış Yüksek Lisans Tezi, Süleyman Demirel Üniversitesi Sosyal Bilimler Enstitüsü, Isparta.

Ulutaş, P. (2017). Öğretmenlerin bakış açısından ögretmenlik mesleğinin toplumsal statüsü. Yayımlanmamış Yüksek Lisans Tezi, Mersin Üniversitesi Eğitim Bilimleri Enstitüsü, Mersin. 
Uygun, S. (2012). Basında öğretmen sorunları. Milli Ĕ̆itim Dergisi, 194, 72-92.

Ünsal, S. (2015). Öğretmenlerin mesleki imajlarına ilişkin görüşleri ve mesleki imaja etki eden faktörler. Yayımlanmamış Doktora Tezi, Gaziantep Üniversitesi Eğitim Bilimleri Enstitüsü, Gaziantep.

Ünsal, S. (2018). Türkiye'de öğretmenlik mesleğinin statüsüne ilişkin bir Pareto analizi. Sakarya University Journal of Education, 8(2), 111-130.

Ünsal, S. ve Bağçeci, B. (2016). Öğretmenlerin mesleki imajlarına ilişkin görüşleri ve mesleki imaja etki eden faktörler. Journal of Human Sciences, 13(3), 3905-3926.

Yavuz, C. (2006). Halkla ilişkiler. Ankara: Detay Yayıncılık.

Yurdakal, İ. H. (2019). Öğretmen adaylarının öğretmenlik mesleğini seçmelerinde rol alan etmenler. Uluslararası Türkçe Edebiyat Kültür Ĕ̈itim Dergisi, 8(2), 1205-1221.

Yurdakul, S., Gür, B. S., Çelik, Z. ve Kurt, T.(2016). Öğretmenlik mesleği ve mesleğin statüsü. Ankara: Eğitim-BirSen Stratejik Araştırmalar Merkezi. 